Article

\title{
Effect of Different Thresholds of Drip Irrigation Using Saline Water on Soil Salt Transportation and Maize Yield
}

\author{
Jingang Li ${ }^{1}$, Zhongyi Qu ${ }^{2,3, *}$, Jin Chen ${ }^{1,4, *}$, Fan Wang ${ }^{5}$ and Qiu Jin ${ }^{6}$ \\ 1 College of Water Conservancy and Hydropower Engineering, Hohai University, Nanjing 210098, China; \\ lijingang68@sina.com \\ 2 Water Conservancy and Civil Engineering College, Inner Mongolia Agricultural University, \\ Hohhot 010018, China \\ 3 Cold and Arid Regions Irrigation and Drainage Research Institute, Inner Mongolia Agricultural University, \\ Hohhot 010018, China \\ 4 College of Agricultural Engineering, Hohai University, Nanjing 210098, China \\ 5 Water Conservancy Science Research Institute of Bayannaoer, Linhe 015000, China; wangfan0201@126.com \\ 6 Nanjing Hydraulic Research Institute, Nanjing 210029, China; qjin@nhri.cn \\ * Correspondence: quzhongyi@imau.edu.cn (Z.Q.); chinsei@163.com (J.C.); Tel.: +86-150-4910-9708 (Z.Q.); \\ +86-139-1298-0055 (J.C.)
}

Received: 11 November 2018; Accepted: 5 December 2018; Published: 14 December 2018

check for updates

\begin{abstract}
Sustainable development of saline water irrigation was restricted in HID (Hetao Irrigation District) by serious yield reduction and severe salt accumulation without an effective irrigation schedule. Field experiments were carried out to study the effects of drip irrigation thresholds on soil salt transportation and maize yield with shallow saline ground water in 2015 and 2016 in HID. The irrigation was triggered by four soil matric potential (SMP) treatments which measured $20 \mathrm{~cm}$ beneath the drip emitter. Results indicate that the shape of the wetting body approximated a one-fourth ellipse on the vertical profile perpendicular to the drip line, while the horizontal radius increased with the increase of SMP. Moreover, salt accumulation decreased with the increasing thresholds in the 0-40-cm layer, while the soil salt in the 40-100 $\mathrm{cm}$ layer was hardly affected by SMP thresholds under a drip irrigation quota of $22.5 \mathrm{~mm}$. Maize yield showed a quadratic relationship with the SMP threshold, and the irrigation water use efficiency (IWUE) showed a linear increase in response to the decrease in SMP threshold. Taking into account the salt accumulation, yield and IWUE, a SMP threshold higher than $-30 \mathrm{kPa}$ is suggested as the appropriate indicator for maize mulched-drip irrigation with shallow saline groundwater in HID.
\end{abstract}

Keywords: shallow saline groundwater; drip irrigation; maize; salt transportation; salt accumulation

\section{Introduction}

HID (Hetao Irrigation District) is one of the largest irrigation regions and most important food production bases in north China. However, due to its arid climate and inadequate drainage systems, $77.7 \%$ of the land area was covered with salt-affected soils in 2012 , soil salinity and water shortages have plagued agriculture production for a long time. The low precipitation and dry climate result in a high dependency of local crops on irrigation water from the Yellow River; approximately 3.92 billion $\mathrm{m}^{3}$ of water is used for irrigation every year, which accounts for $98 \%$ of the total water taken by channels from the Yellow River by HID. The vast amount of agricultural water used not only leads to heavy stress on ecological water but also contributes to the drying up of the Yellow River. Meanwhile, the contradiction between the increasing water shortage and heavy demands has been notable. Moreover, shallow soil 
salt has accumulated after years of cultivation as a result of mismanagement of water and fertilizer, high groundwater table, arid climate, decreased infiltrability and inadequate drainage systems. Viable strategies are necessary to alleviate the water shortage and ameliorate surface soil salinization while under the demands for enormous yields.

So far, many countermeasures have been put forward to reduce the vast amount of irrigation water used, summarized as employing water-saving irrigation techniques, reforming canal seepage control, delivering irrigation water with pipelines instead of canals, exploiting new irrigation water resources (such as reclaimed water and saline water), applying rational organic fertilizer, cultivating salt-tolerant plants, constructing drainage systems, and ponding fresh water on the soil surface to leach soil salts [1,2]. However, due to the typical inland arid conditions and fresh water shortages in north China, it is not practical to utilize any single management strategy of those mentioned above. Accordingly, a novel and feasible method is needed to reduce the amount of fresh irrigation water used and to decrease the trend of soil salinization.

In this sense, the conjunctive use of surface and groundwater for mulched-drip irrigation is purported to be the most efficient and practical method in HID, which has considerable storage of shallow saline groundwater-approximately 0.72 billion $\mathrm{m}^{3}$, according to an investigation carried out in 2013 and 2014. On the one hand, established canals can be used to carry fresh Yellow River water for leaching soil salt appropriately after crop harvesting or before ploughing; on the other hand, an optimum scheme of mulched-drip irrigation with saline water can reduce fresh water consumption effectively during the growing period. Consequently, combined application of canals and wells can be an important means of sustainable water resource utilization and soil desalinization in HID.

Researchers have indicated that groundwater of poor quality can be used to ameliorate the urgent demand for fresh water in agriculture in water-deficient areas such as HID [3,4]. Moreover, Ma et al. (2010) indicated that favorable brackish water irrigation at the electrical conductivity of $5.6 \mathrm{ds} / \mathrm{m}$ can obtain desirable yields and not lead to soil salinization [5]. Due to the advantages of distributing water and nutrients uniformly, controlling the amount of applied water precisely at high frequencies, reducing evaporation by plastic mulch, minimizing deep percolation with normal irrigation quota, and decreasing the adverse effects of salinity by means of leaching [6-8], mulched-drip irrigation is asserted to be the most effective method for saline water irrigation. The use of plastic mulch associated with drip irrigation would decrease salt accumulation on the soil surface as direct evaporation of water to air is minimized; furthermore, the mulch also increases the soil temperature and moisture to ensure high emergence growth rates of crop seedlings [9-11]. Wang et al. (2016) indicated that mulched-drip irrigation with saline water at a salinity of $3.0 \mathrm{~g} / \mathrm{L}$ can guarantee the yield of cotton, while the soil salt conditions will not be affected at the same time [12]. The key issue related to the utilization of saline water instead of fresh water on salt-affected soils is to determine a reasonable irrigation schedule to ensure appropriate irrigation water for both normal crop growth and soil desalination. Extensive research has suggested that the measurement of soil matric potential (SMP) at a depth of $20 \mathrm{~cm}$ immediately under the drip emitter can be used as an indicator for crop drip irrigation scheduling [13-20]. Based on experiments, Kang et al. (2005) indicate that soil moisture and salinity condition can be well maintained if the SMP of mulched-drip irrigation with saline water is kept higher than $-20 \mathrm{kPa}$ [13].

However, the salt contents, soil texture, ion composition of shallow saline groundwater and climate conditions in HID are quite different. Moreover, few studies apply shallow saline groundwater, in which salt contents fluctuate during the maize growth period, compared with saline water prepared with freshwater and chemicals in laboratory. Thus, further studies of saline water and mulched-drip irrigation are needed in HID. In order to analyze the effect of different thresholds of drip irrigation using shallow saline groundwater on soil salt and crop yield, open-field research was conducted in HID for maize under mulched-drip irrigation with local groundwater by controlling different SMPs at 20-cm depth immediately under the emitters. 
The objectives of this study were to: (1) determine the effect of different SMPs on spatial distribution of volumetric soil moisture and soil salt; (2) measure the impact of different SMPs on salt accumulation, maize yield and irrigation water use efficiency (IWUE); and (3) optimize proper irrigation scheduling for maize shallow saline groundwater irrigation in HID.

\section{Materials and Methods}

\subsection{Experimental Site}

The field experiment was conducted at Wulate Qianqi Water Saving and Ecological Experiment Station (longitude: $107^{\circ} 13^{\prime}$ E, latitude: $40^{\circ} 43^{\prime}$ N, $1041 \mathrm{~m}$ a.s.l., HID of Inner Mongolia Autonomous Region, China), from 15 April to 30 November 2015, and 12 April to 26 November 2016. The station is in the east part of north China with a typical continental desert climate, and characterized by scarce precipitation (about $225 \mathrm{~mm}$ annually, most of which (78.9\%) falls between June and September), strong evaporation (more than $2200 \mathrm{~mm}$, approximately ten times annual rainfall), and long sunshine hours (about $3156 \mathrm{~h}$ annually). Daily rainfall, maximum temperature and minimum temperature data are shown in Figure 1. The average air temperatures in 2015 and 2016 were $18.43{ }^{\circ} \mathrm{C}$ and $19.02{ }^{\circ} \mathrm{C}$, respectively, while the annual average humidity is $45 \%$. The soil of the field is mainly loamy sand and its physicochemical properties are presented in Tables 1-3.

Crops are usually irrigated with fresh water carried from the Yellow River by canals. The groundwater table of the experimental field varies from 0.79 to $3.87 \mathrm{~m}$, and the average ground water depth was about $2.74 \mathrm{~m}$ in 2015 and $2.78 \mathrm{~m}$ in 2016 during the maize growth period. The total dissolved solids of local groundwater varied from 2.22 to $3.64 \mathrm{~g} / \mathrm{L}$ during the experimental period, and averaged $3.14 \mathrm{~g} / \mathrm{L}$ in 2015 and $3.12 \mathrm{~g} / \mathrm{L}$ in 2016. The ionic composition of shallow groundwater and Yellow River water is given in Table 4 , and the variation of the groundwater table and salinity is shown in Figure 2.

Table 1. Soil physical properties in the experimental region.

\begin{tabular}{|c|c|c|c|c|c|c|}
\hline \multirow{2}{*}{$\begin{array}{l}\text { Soil Depth } \\
\text { (cm) }\end{array}$} & \multirow{2}{*}{$\begin{array}{c}\text { Bulk } \\
\text { Density } \\
\left(\mathrm{g} \cdot \mathrm{cm}^{-3}\right)\end{array}$} & \multirow{2}{*}{$\begin{array}{c}\text { Field } \\
\text { Capacity }(\%)\end{array}$} & \multirow{2}{*}{$\begin{array}{c}\text { Texture } \\
\text { Class }\end{array}$} & \multicolumn{3}{|c|}{ Mechanical Composition (\%) } \\
\hline & & & & $\begin{array}{c}\text { Clay } \\
(<0.002 \mathrm{~mm})\end{array}$ & $\begin{array}{c}\text { Silt } \\
(0.002-0.05 \mathrm{~mm})\end{array}$ & $\begin{array}{c}\text { Sand } \\
(0.05-2.0 \mathrm{~mm})\end{array}$ \\
\hline $0-40$ & 1.38 & 32.8 & Loam & 4.58 & 32.10 & 63.32 \\
\hline $40-60$ & 1.47 & 18.6 & Loamy sand & 1.46 & 11.34 & 87.20 \\
\hline $60-100$ & 1.42 & 26.2 & Sandy loam & 2.28 & 26.30 & 71.42 \\
\hline
\end{tabular}

Table 2. Basic soil nutrient of the initial profile.

\begin{tabular}{|c|c|c|c|c|c|c|}
\hline $\begin{array}{l}\text { Soil Depth } \\
\text { (cm) }\end{array}$ & $\begin{array}{l}\text { Total N } \\
\text { (g/kg) }\end{array}$ & $\begin{array}{l}\text { Total P } \\
\text { (g/kg) }\end{array}$ & $\begin{array}{c}\text { Available N } \\
\text { (mg/kg) }\end{array}$ & $\begin{array}{c}\text { Available } P \\
\text { (mg/kg) }\end{array}$ & $\begin{array}{c}\text { Available K } \\
\text { (mg/kg) }\end{array}$ & $\begin{array}{c}\text { Organic } \\
\text { Matter }(\mathrm{g} / \mathrm{kg})\end{array}$ \\
\hline $0-40$ & 0.20 & 0.28 & 29.34 & 0.52 & 102.26 & 2.06 \\
\hline $40-60$ & 0.14 & 0.36 & 15.20 & 0.43 & 76.90 & 1.58 \\
\hline 60-100 & 0.10 & 0.25 & 7.00 & 0.64 & 68.54 & 1.40 \\
\hline
\end{tabular}

Table 3. Basic soil salinity of the initial profile.

\begin{tabular}{|c|c|c|c|c|c|c|c|c|c|}
\hline \multirow{2}{*}{$\begin{array}{l}\text { Soil Depth } \\
\text { (cm) }\end{array}$} & \multicolumn{8}{|c|}{ Composition of Soil: Water 1:5 (w/v) Extract (mmol/L) } & \multirow{2}{*}{$\begin{array}{l}\text { Soil Salinity } \\
\quad\left(\mathrm{g} \cdot \mathrm{kg}^{-1}\right)\end{array}$} \\
\hline & $\mathrm{CO}_{3}{ }^{2-}$ & $\mathrm{HCO}_{3}^{-}$ & $\mathrm{Cl}^{-}$ & $\mathrm{SO}_{4}^{2-}$ & $\mathrm{Ca}^{2+}$ & $\mathrm{Mg}^{2+}$ & $\mathrm{Na}^{+}$ & $\mathrm{K}^{+}$ & \\
\hline $0-40$ & 0.03 & 0.92 & 43.28 & 14.58 & 12.36 & 1.88 & 44.12 & 0.45 & 2.92 \\
\hline $40-60$ & 0.03 & 0.56 & 38.34 & 28.42 & 18.42 & 2.02 & 46.08 & 0.83 & 2.03 \\
\hline 60-100 & 0.00 & 0.62 & 42.55 & 18.69 & 14.64 & 3.43 & 42.56 & 1.23 & 2.51 \\
\hline
\end{tabular}


Table 4. Compositions of shallow groundwater and Yellow River water.

\begin{tabular}{cccccccccccc}
\hline & \multicolumn{9}{c}{ Ionic Concentration (mmol/L) } & \multirow{2}{*}{$\mathbf{E C}(\mathbf{d s} / \mathbf{m})$} & $\mathbf{p H}$ \\
\cline { 2 - 9 } & $\mathbf{C O}_{3}{ }^{2-}$ & $\mathbf{H C O}_{3}{ }^{-}$ & $\mathbf{C l}^{-}$ & $\mathbf{S O}_{4}{ }^{2-}$ & $\mathbf{C a}^{2+}$ & $\mathbf{M g}^{2+}$ & $\mathbf{N a}^{+}$ & $\mathbf{K}^{+}$ & & \\
\hline Shallow groundwater & 189.10 & 99.10 & 559.20 & 667.60 & 315.00 & 202.00 & 1298.70 & 39.00 & 3.37 & 8.47 \\
Yellow River water & 9.25 & 101.74 & 60.55 & 89.24 & 73.23 & 52.45 & 100.11 & 7.80 & 0.49 & 7.5 \\
\hline
\end{tabular}

Note: "EC" indicates electric conductivity of water.

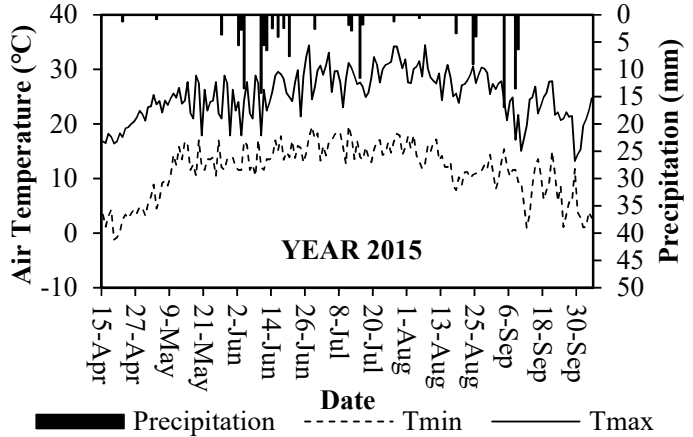

(a)

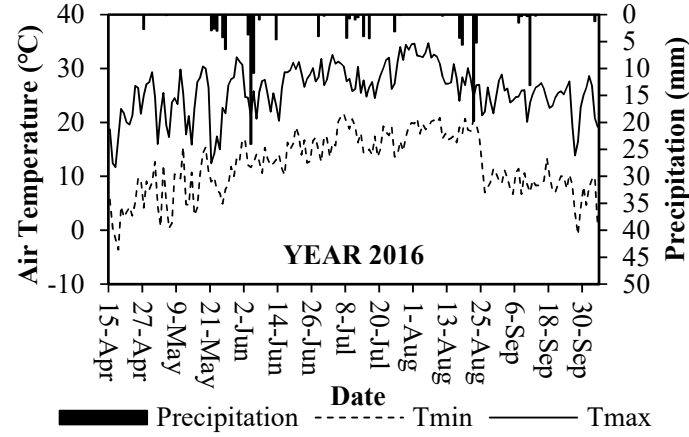

(b)

Figure 1. Daily meteorological data during the crop growth period for 2015 and 2016: (a) daily meteorological data for 2015; (b) daily meteorological data for 2016.

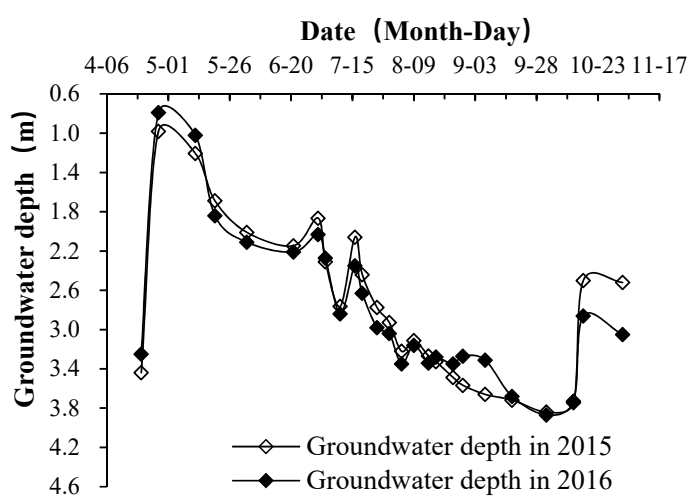

(a)

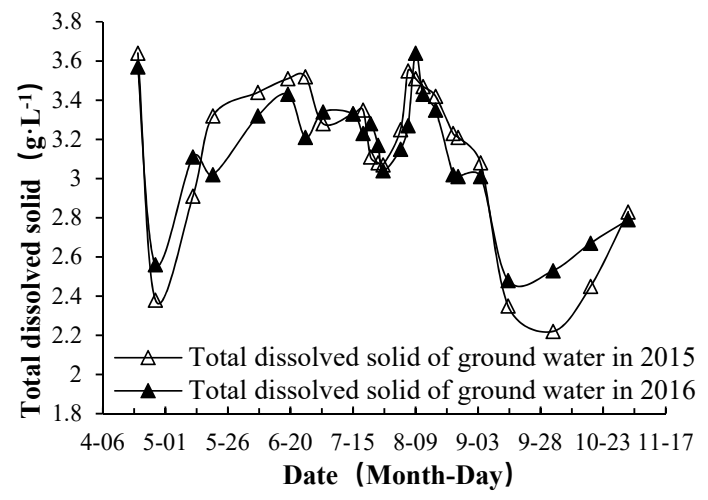

(b)

Figure 2. Variation of the groundwater table and salinity: (a) variation of groundwater depth; (b) variation of groundwater salinity.

\subsection{Experimental Design}

\subsubsection{Plot Layout, Irrigation Water Management}

Field experiments were carried out in 12 plots, each covering an area of $324.0 \mathrm{~m}^{2}(7.2 \mathrm{~m} \times 45.0 \mathrm{~m})$. Four treatments in terms of SMP value were devised at $20 \mathrm{~cm}$ depth immediately under the emitters higher than $-10 \mathrm{kPa}(\mathrm{S} 1),-20 \mathrm{kPa}(\mathrm{S} 2),-30 \mathrm{kPa}(\mathrm{S} 3),-40 \mathrm{kPa}(\mathrm{S} 4)$ after maize establishment. The four treatments were replicated 3 times with the experimental plots following a completely randomized block design. Each plot contained 6 raised beds with spacing and length of $1.2 \mathrm{~m}$ and $35.0 \mathrm{~m}$, respectively.

Each treatment was equipped with an independent drip irrigation system, which consisted of valves, a water flow meter, a pressure gauge, a fertilizer tank, a screen filter and 6 tapes. Thin-wall drip tapes (Shanghai Huawei Co. Shanghai, China) with $0.3 \mathrm{~m}$ emitter intervals and a flow rate of $1.38 \mathrm{~L} / \mathrm{h}$ at the operating pressure of $0.1 \mathrm{MPa}$ were placed on the center of raised beds, and then white 
polyethylene films ( $90.0 \mathrm{~cm}$ width and about $0.038 \mathrm{~mm}$ thick) were spread over each bed. The location of the treatments was settled during the 2 years of the experiments.

All experimental treatments were performed by spring irrigation with Yellow River water of $112.5 \mathrm{~mm}$ after cultivation and 20 days before sowing to ensure appropriate salt and moisture environment in surface soil for seedlings to emerge normally. Thereafter $22.5 \mathrm{~mm}$ of saline water pumped from a local phreatic aquifer was applied when SMP reached the target values.

\subsubsection{Plant Management and Measurements}

Maize (Neidan No. 212, a crossbred variety selected by Maize Research Institute of Inner Mongolia Academy of Agricultural \& Animal Husbandry Sciences, China) were sown at $20 \mathrm{~cm}$ intervals on 8 May 2015 and 14 May 2016 in double rows, with each row lying about $25 \mathrm{~cm}$ away from the drip line (Figure 3). Thinning was conducted on the 13th and 12th day in 2015 and 2016, respectively. Maize was harvested on 30 September and 4 October, and the growth period was 145 and 143 days in 2015 and 2016, respectively. Basal-dressing dose of $375 \mathrm{~kg} / \mathrm{ha}$ of diammonium phosphate (DAP: $18 \% \mathrm{~N}, 46 \% \mathrm{P}$, $0 \% \mathrm{~K})$ and $135 \mathrm{~kg} / \mathrm{ha}$ of potassium sulphate $\left(\mathrm{K}_{2} \mathrm{SO}_{4}, 45 \%\right)$ were uniformly applied to the experimental plots at the time of mulching in 2015 and 2016. The top-dressing was supplemented with urea $(46.2 \%$ $\mathrm{N})$ and compound fertilizer $\left(12 \% \mathrm{~N}, 18 \% \mathrm{P}_{2} \mathrm{O}_{5}, 15 \% \mathrm{~K}_{2} \mathrm{O}\right)$, which was applied by mixing with irrigation water at a concentration of $30 \%(\mathrm{w} / \mathrm{w})$; the detailed top-dressing scheme is given in Table 5 . Disease and pest management practices were the same as those used for local traditional corn production.

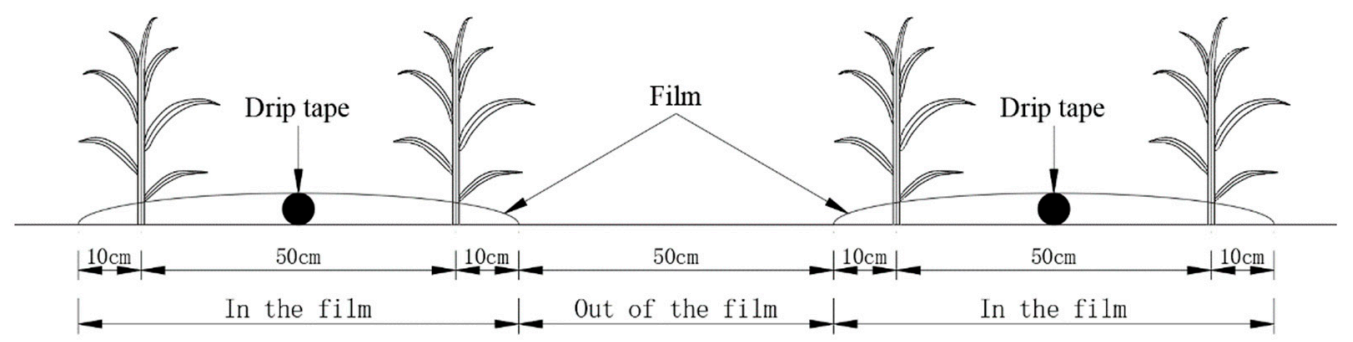

Figure 3. Layout of drip lines.

Table 5. Detail top-dressing scheme.

\begin{tabular}{|c|c|c|c|c|c|c|c|c|c|}
\hline Time & $\begin{array}{l}\text { Before } \\
\text { Sowing }\end{array}$ & $\begin{array}{l}\text { Late } \\
\text { June }\end{array}$ & $\begin{array}{l}\text { Early } \\
\text { July }\end{array}$ & $\begin{array}{l}\text { Mid } \\
\text { July }\end{array}$ & $\begin{array}{l}\text { Late } \\
\text { July }\end{array}$ & $\begin{array}{c}\text { Early } \\
\text { August }\end{array}$ & $\begin{array}{c}\text { Mid } \\
\text { August }\end{array}$ & $\begin{array}{c}\text { Late } \\
\text { August }\end{array}$ & Annual \\
\hline $\begin{array}{l}\text { Diammonium } \\
\text { phosphate }\end{array}$ & $375 \times 1$ & & & & & & & & 375 \\
\hline $\begin{array}{l}\text { Potassium } \\
\text { sulphate }\end{array}$ & $135 \times 1$ & & & & & & & & 135 \\
\hline Urea & & $45 \times 1$ & $45 \times 1$ & $45 \times 1$ & $45 \times 2$ & $45 \times 2$ & $45 \times 2$ & $45 \times 1$ & 450 \\
\hline $\begin{array}{l}\text { compound } \\
\text { fertilizer }\end{array}$ & & $45 \times 1$ & & $45 \times 1$ & & & $45 \times 1$ & & 135 \\
\hline
\end{tabular}

Note: “375 × 1" indicates fertilization once and $375 \mathrm{~kg} / \mathrm{ha}$ of diammonium phosphate was fertilized before sowing.

The finial emergence percentage was measured after thinning for each plot and calculated on the number of hills.

\subsection{Observation and Equipment}

\subsubsection{Rainfall and Equipment}

Meteorological data, containing daily rainfall, wind speed, and maximum temperature, were obtained from an automatic weather station (YM-03A) located $50 \mathrm{~m}$ away from the field experiment site. The precipitation during the maize growth stage was $145.88 \mathrm{~mm}$ and $139.7 \mathrm{~mm}$ in 2015 and 2016, respectively. 


\subsubsection{Soil Matric Potential}

A vacuum gauge tensiometer was installed at $20 \mathrm{~cm}$ depth immediately under the emitter for SMP monitoring and irrigation scheduling in each plot. The tensiometers were observed 3 times per day at 08:00, 12:00, and 18:00 $\mathrm{h}$ during the whole growth period of maize.

\subsubsection{Soil Salinity and Moisture}

Soil samples were obtained from each plot with an auger $(2.0 \mathrm{~cm}$ in diameter and $15 \mathrm{~cm}$ high) every 20 days from sowing to harvesting in each plot in 2015 and 2016. Additional measurements were taken before and after each irrigation event. The distances of sampling points to drip emitters were $0,17.5,35$, and $60 \mathrm{~cm}$, and all the samples depths were the same, that is, $0-10,10-20,20-30$, $30-40,40-60,60-80$, and $80-100 \mathrm{~cm}$. The 3 replications of soil samples per treatment were mixed into 1 sample for testing and analysis of the soil salinity and water content. Soil moisture content was measured by gravimetric method, and converted to volumetric soil moisture content by multiplying soil bulk density.

All samples were air-dried, ground and passed through a 1-mm sieve. Soil leachate was prepared at a soil-to-water ratio of 1:5 and soil salinity was estimated from electrical conductivity $\mathrm{EC}_{1: 5}$ measured with a conductivity meter (DDS-11A, REX, Shanghai). The formula for converting electrical conductivity to soil salt concentration was calibrated with experimental data, which exhibited a linear relationship between $\mathrm{EC}_{1: 5}$ and soil salt content (Figure 4).

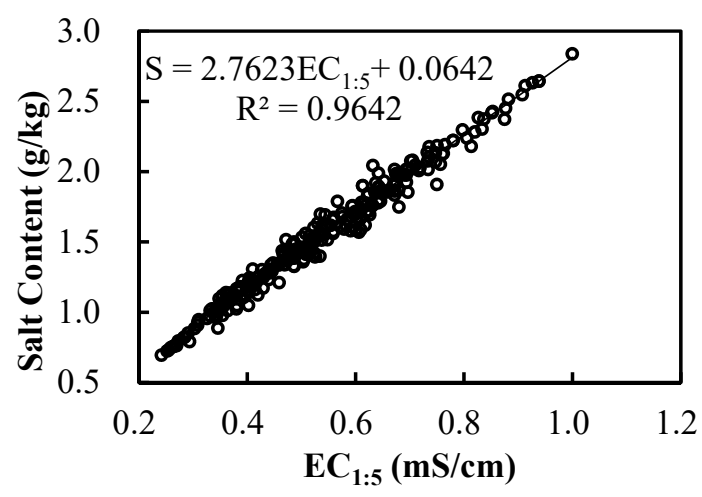

Figure 4. Relationship between soil salt concentration and soil $\mathrm{EC}_{1: 5}$.

\subsubsection{Maize Yield}

At maize harvest in late September 2015 and early October 2016, a harvest area of $12 \mathrm{~m}^{2}(5.0 \mathrm{~m}$ in length and $2.4 \mathrm{~m}$ in width) was randomly selected, and yield was then estimated by the following equation:

$$
\mathrm{Y}=\frac{10,000}{12} \times \mathrm{y}
$$

where $\mathrm{Y}$ is the estimated maize yield ( $\mathrm{kg} / \mathrm{ha})$, and $\mathrm{y}$ is the measured maize yield in the selected area $\left(\mathrm{kg} / \mathrm{m}^{2}\right)$.

\subsubsection{Calculation of IWUE}

IWUE can be calculated by the following equation:

$$
\text { IWUE }=\frac{Y}{\mathrm{I}}
$$

where $\mathrm{Y}$ is maize yield $(\mathrm{kg} / \mathrm{ha})$, and I is the irrigation amount $(\mathrm{mm})$ during the maize growth stages. 


\subsubsection{Statistical Analysis}

The soil water content, yield and soil salinity were analyzed with Excel 2016, Surfer 12.2.705 and SPSS 20, while layout of drip lines was drawn using AutoCAD 2016. Single-factor analysis of variance (ANOVA) and multiple comparisons were conducted for significance effects among treatments with the least-significant difference (LSD) test using SPSS 20, and at a $\alpha=0.05$ level of significance.

\section{Results}

\subsection{Irrigation Management and Weather}

The cumulative rainfall during the experiment period is shown in Figure 5; the total rainfall during the period was $145.88 \mathrm{~mm}$ in 2015 and $139.7 \mathrm{~mm}$ in 2016. Moreover, precipitation exceeded $5 \mathrm{~mm} 10$ and 7 times in 2015 and 2016, respectively; consequently, the corresponding totals were 102.73 and $84.8 \mathrm{~mm}$, respectively. In 2015 and 2016, respectively, $70.98 \%$ and $72.44 \%$ of rainfall was concentrated in June, July and August.

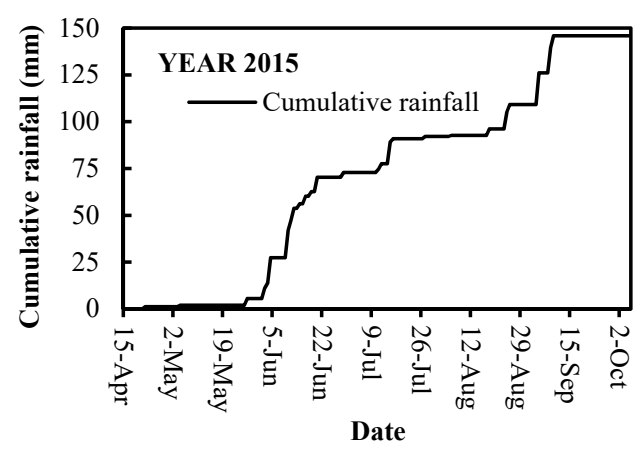

(a)

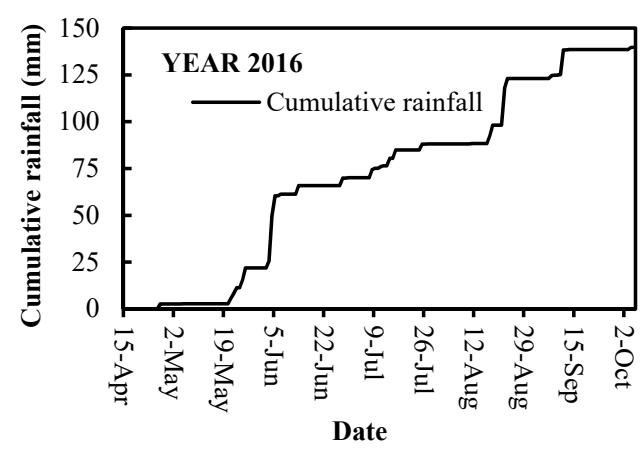

(b)

Figure 5. Cumulative rainfall in 2015 and 2016: (a) cumulative rainfall from 15 April to 5 October in 2015; (b) cumulative rainfall from 15 April to 5 October in 2016.

In order to ameliorate the moisture and salt conditions of the topsoil for better germination, all of the treatments were irrigated with the same amount $(112.5 \mathrm{~mm})$ of Yellow River water before maize sowing. Subsequently, irrigation was applied promptly as the SMP reached the target values for S1, S2, S3, and S4 treatments, respectively. Specifically, considering the maximum evapotranspiration in $\mathrm{HID}$ is $10 \mathrm{~mm} /$ day, and the extra water required for leaching soil salt under saline water irrigation, the same quota of irrigation water of $22.5 \mathrm{~mm}$ for each application was settled during the maize growth period. The irrigation times and amount of applied water for each treatment in 2015 and 2016 is shown in Table 6. Clearly the irrigation frequency and amount of irrigation water increased with the increase of the soil SMPs.

Table 6. Irrigation and amount of applied water for each treatment during the experiment period in 2015 and 2016.

\begin{tabular}{|c|c|c|c|c|c|}
\hline \multirow{2}{*}{ Years } & \multirow{2}{*}{ Treatments } & \multirow{2}{*}{ Fresh Water beforeSowing (mm) } & \multicolumn{2}{|c|}{ Saline Water Irrigation during Experiment } & \multirow{2}{*}{ Water Depth (mm) } \\
\hline & & & Irrigation Times & Seasonal Water Depth (mm) & \\
\hline \multirow{4}{*}{2015} & $\mathrm{~S} 1(-10 \mathrm{kPa})$ & 112.5 & 21 & 472.5 & 585.0 \\
\hline & $\mathrm{S} 2(-20 \mathrm{kPa})$ & 112.5 & 16 & 360.0 & 472.5 \\
\hline & $\mathrm{S} 3(-30 \mathrm{kPa})$ & 112.5 & 13 & 292.5 & 405.0 \\
\hline & $\mathrm{S} 4(-40 \mathrm{kPa})$ & 112.5 & 10 & 225.0 & 337.5 \\
\hline \multirow{4}{*}{2016} & $\mathrm{~S} 1(-10 \mathrm{kPa})$ & 112.5 & 24 & 540.0 & 652.5 \\
\hline & $\mathrm{S} 2(-20 \mathrm{kPa})$ & 112.5 & 18 & 405.0 & 517.5 \\
\hline & $\mathrm{S} 3(-30 \mathrm{kPa})$ & 112.5 & 14 & 315.0 & 427.5 \\
\hline & $\mathrm{S} 4(-40 \mathrm{kPa})$ & 112.5 & 11 & 247.5 & 360.0 \\
\hline
\end{tabular}




\subsection{Distribution of Soil Moisture}

Soil moisture was mainly influenced by evaporation, root water uptake, recharge of groundwater, infiltration of rainfall and irrigation. As Figure 6A-E and Figure 7A-E show, the spatial distributions and variation tendency of soil moisture along the vertical profiles perpendicular to the drip line were similar in 2015 and 2016. Before spring irrigation, a relatively homogeneous region of moisture in the upper $40 \mathrm{~cm}$ existed, and the value of soil moisture averaged $18 \%$, then the soil moisture slightly increased to $24 \%$ at the $60-100 \mathrm{~cm}$ depth (Figures $6 \mathrm{~A}$ and $7 \mathrm{~A}$ ).

Before sowing, the soil moisture of observed layers clearly increased when compared with the values before spring irrigation, and the average soil moisture at $0-30 \mathrm{~cm}$ distance from the drip emitter at $20-40 \mathrm{~cm}$ depth was about $96 \%$ of field capacity, while the value at $80-100 \mathrm{~cm}$ depth was about $98.5 \%$ of field capacity. Specifically, a one-quarter circle area of soil moisture took place at $40-60 \mathrm{~cm}$ distance from the drip emitter above $20 \mathrm{~cm}$ depth, and the soil water content decreased with observed zones away from the emitter and close to the surface.

Before and after the irrigation at the jointing stage, the distribution of soil water for different treatments was similar, and the mean soil moisture content in the interval $0-40 \mathrm{~cm}$ from the drip emitter at $0-40 \mathrm{~cm}$ depth was about $92.4 \%, 78.8 \%, 67.4 \%$ and $62.3 \%$ of field capacity before the irrigation and around $97.2 \%, 91.46 \%, 91.42 \%$ and $88.4 \%$ of field capacity after the irrigation for $-10 \mathrm{kPa},-20 \mathrm{kPa}$, $-30 \mathrm{kPa}$ and $-40 \mathrm{kPa}$ treatments, respectively. In particular, at the interval of $40-60 \mathrm{~cm}$ from the emitter, soil moisture in all treatments reached the minimum value and in the order of $-10 \mathrm{kPa}>$ $-20 \mathrm{kPa}>-30 \mathrm{kPa}>-40 \mathrm{kPa}$. Soil water content at depth $80-100 \mathrm{~cm}$ remained unchanged for all treatments. It is clear that soil moisture in the $40-60 \mathrm{~cm}$ layer is less than that of the upper $(0-40 \mathrm{~cm})$ and the lower $(60-100 \mathrm{~cm})$ layers. This can be attributed to the texture of the $40-60 \mathrm{~cm}$ soil layer, which is loamy sand and has lower field capacity than the other two layers.

After harvest, soil water content in the 40-100 cm layer was similar for all treatments and averaged $15 \%$ in $40-60 \mathrm{~cm}, 20 \%$ in $60-80 \mathrm{~cm}$ and $24.5 \%$ in $80-100 \mathrm{~cm}$. The moisture at $0-40 \mathrm{~cm}$ distance from the drip emitter in the $0-40 \mathrm{~cm}$ layer for $-10 \mathrm{kPa}$ and $-30 \mathrm{kPa}$ treatments were higher than that for $-20 \mathrm{kPa}$ and $-40 \mathrm{kPa}$ treatments, whereas, soil distribution at 40-60 $\mathrm{cm}$ distance from the drip emitter in the $0-30 \mathrm{~cm}$ layer was similar, with soil moisture in the order of $-10 \mathrm{kPa}>-20 \mathrm{kPa}>-30 \mathrm{kPa}>$ $-40 \mathrm{kPa}$.

The horizontal radius of the wetting body in the profile perpendicular to the drip line increased with the increase of SMP measured $20 \mathrm{~cm}$ beneath the drip emitter, while the vertical radius was $40 \mathrm{~cm}$ as the SMP varied from $-10 \mathrm{kPa}$ to $-40 \mathrm{kPa}$. Furthermore, the humidity in the mulch was higher than that out of the mulch, as the plastic membrane served the function of minimizing the evaporation of topsoil and maintaining the moisture of the micro environment; accordingly, little soil water moved upward with capillary force for evaporation in the mulch. Moreover, the horizontal and vertical infiltration of irrigation water increased soil moisture, thus, soil water content at $0-40 \mathrm{~cm}$ distance from the drip emitter was higher than that at 40-60 cm distance from the drip emitter in the same layer. Additionally, influenced by the recharge of groundwater, soil moisture at $60-100 \mathrm{~cm}$ remained stable. 


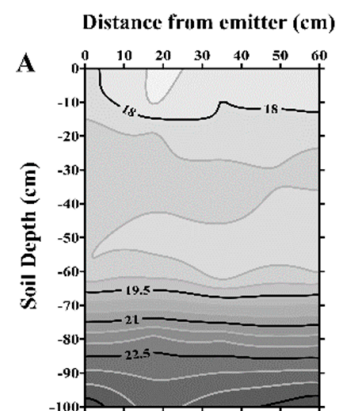

$-10 \mathrm{kPa}$

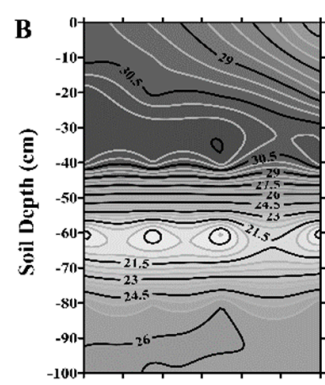

$-10 \mathrm{kPa}$

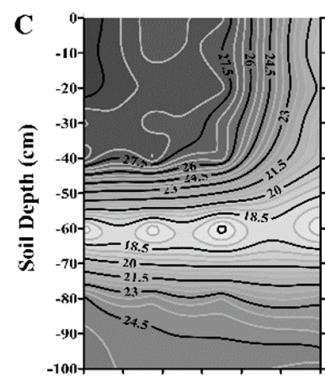

$-10 \mathrm{kPa}$

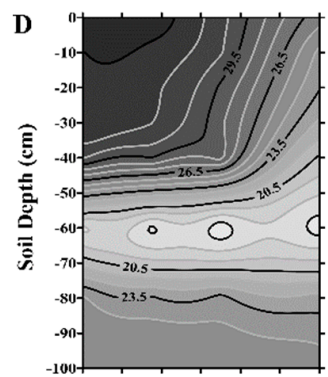

$-10 \mathrm{kPa}$

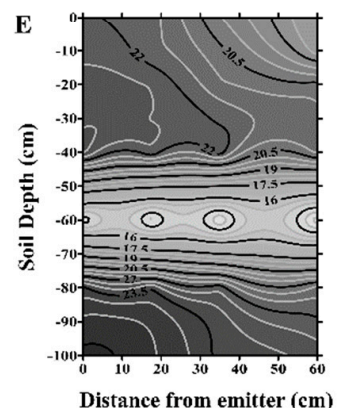

$-10 \mathrm{kPa}$

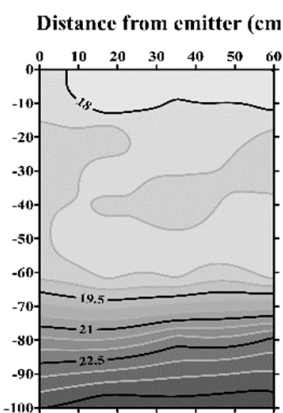

$-20 \mathrm{kPa}$

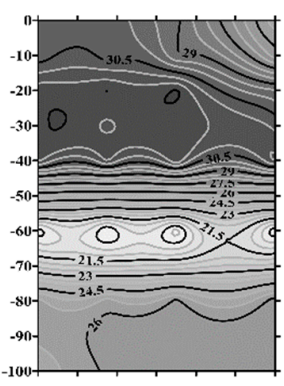

$-20 \mathrm{kPa}$

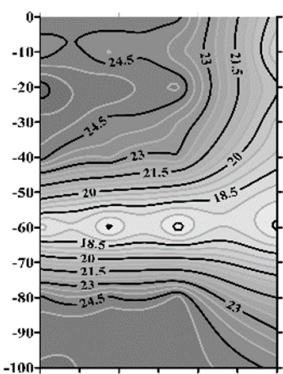

$-20 \mathrm{kPa}$

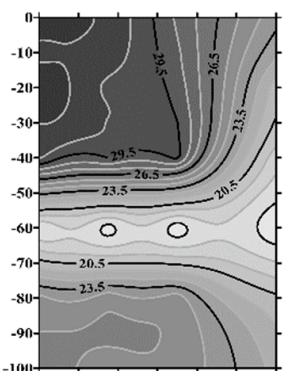

-20 kPa

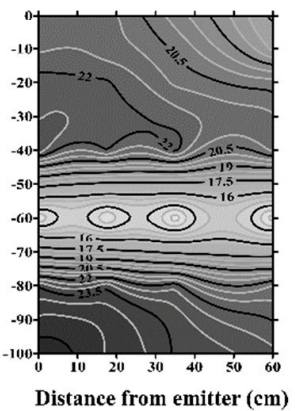

$-20 \mathrm{kPa}$

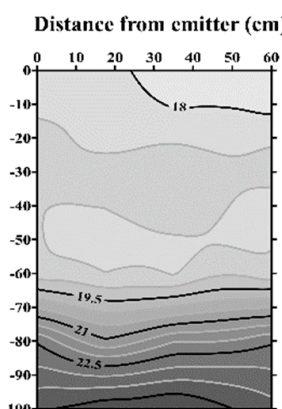

$-30 \mathrm{kPa}$

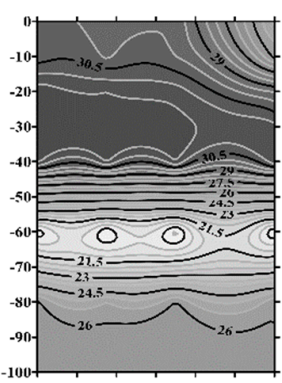

$-30 \mathrm{kPa}$

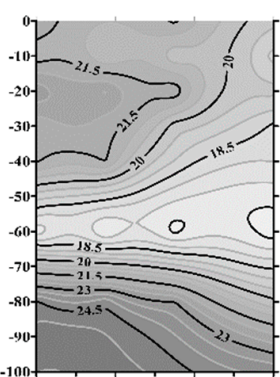

$-30 \mathrm{kPa}$

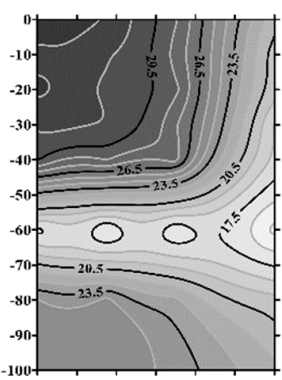

$-30 \mathrm{kPa}$

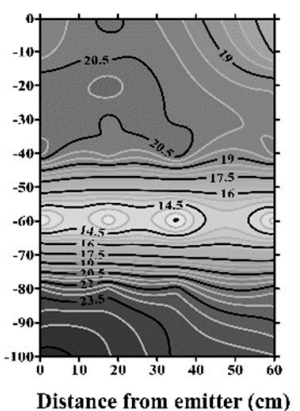

$-30 \mathrm{kPa}$

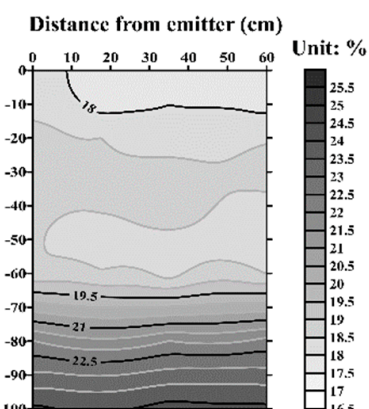

$-40 \mathrm{kPa}$

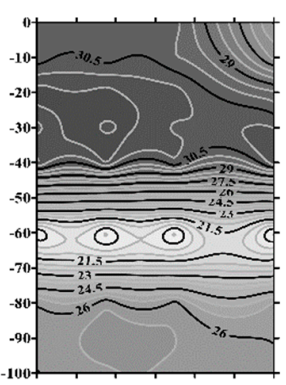

Unit: \%

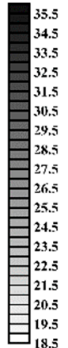

$-40 \mathrm{kPa}$
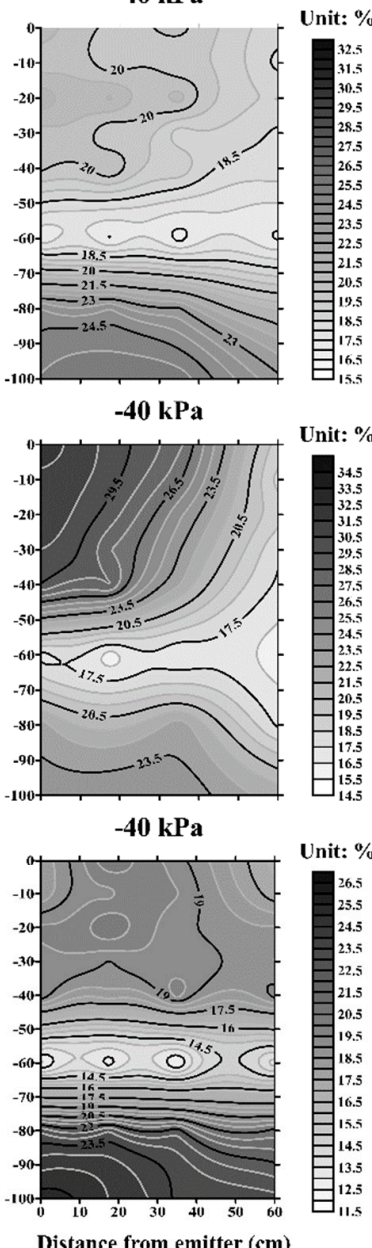

$-40 \mathrm{kPa}$

Figure 6. Spatial distribution of soil moisture along the vertical transect that is perpendicular to the drip line (A) before spring irrigation, (B) before sowing, (C) before the irrigation at the jointing stage, (D) after the irrigation at the jointing stage, and (E) after harvest, for all treatments in 2015. 


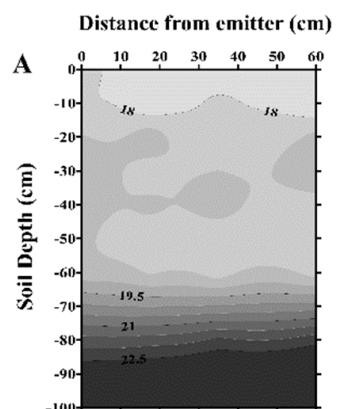

$-10 \mathrm{kPa}$

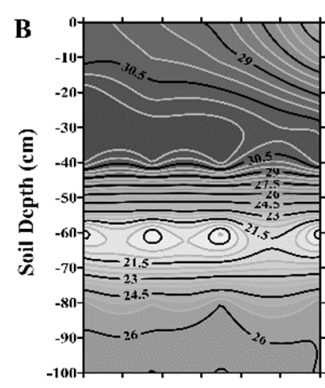

$-10 \mathrm{kPa}$

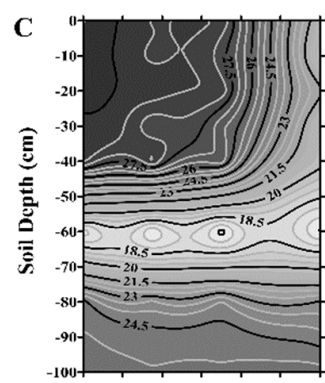

$-10 \mathrm{kPa}$

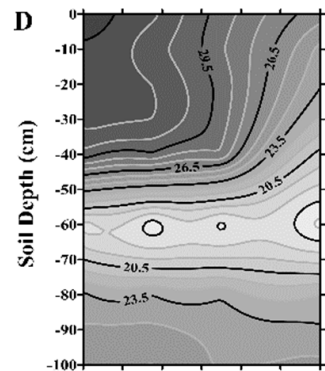

$-10 \mathrm{kPa}$

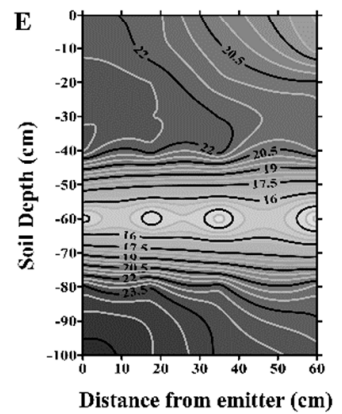

$-10 \mathrm{kPa}$

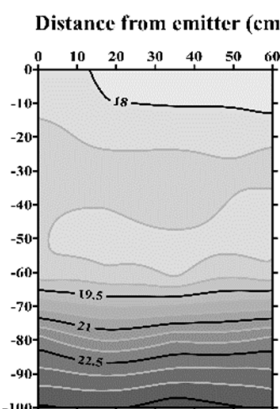

$-20 \mathrm{kPa}$

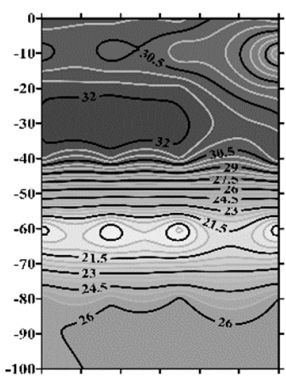

$-20 \mathrm{kPa}$

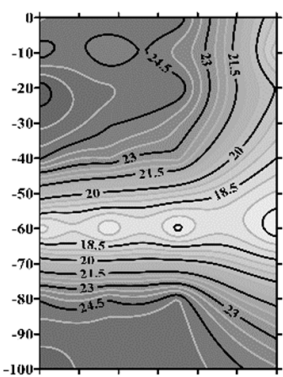

$-20 \mathrm{kPa}$

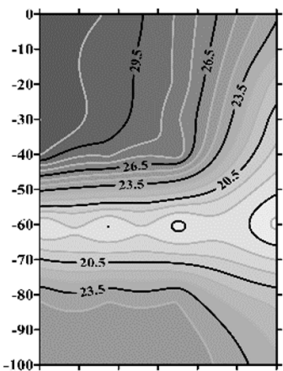

$-20 \mathrm{kPa}$

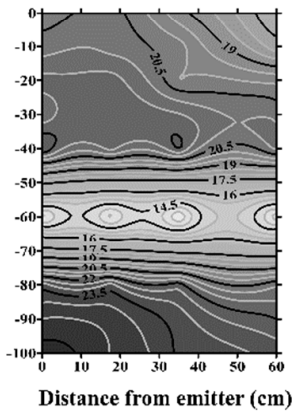

$-20 \mathrm{kPa}$

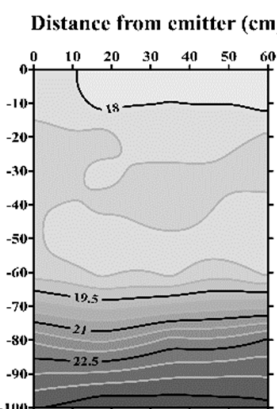

$-30 \mathrm{kPa}$

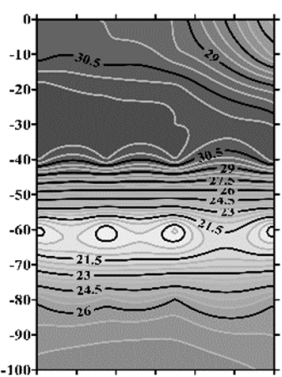

$-30 \mathrm{kPa}$

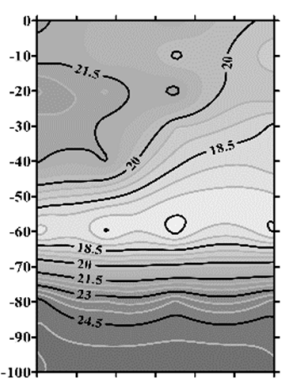

$-30 \mathrm{kPa}$

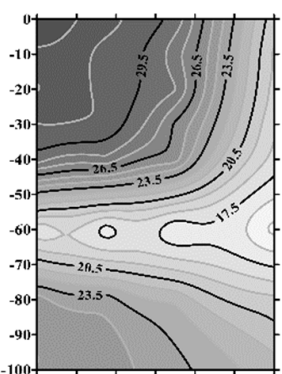

$-30 \mathrm{kPa}$

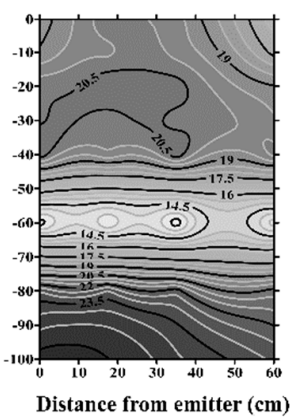

$-30 k P a$

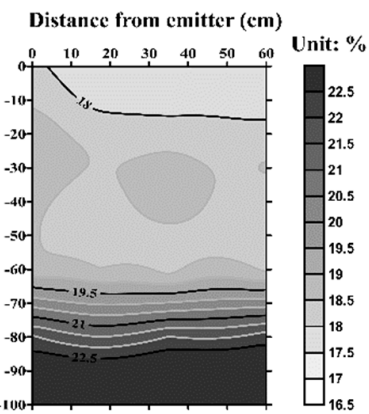

$-40 \mathrm{kPa}$

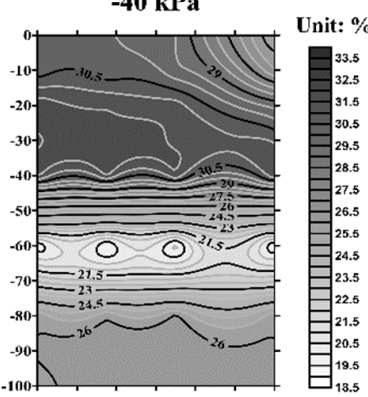

$-40 \mathrm{kPa}$

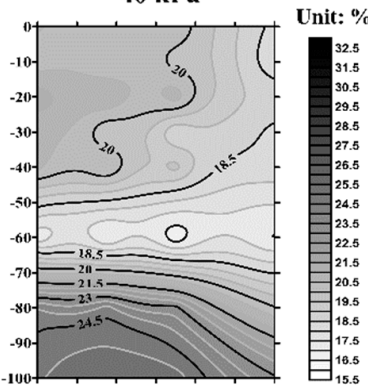

$-40 \mathrm{kPa}$

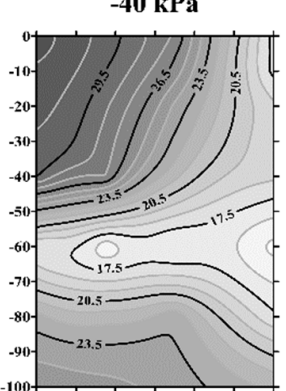

Unit: \%
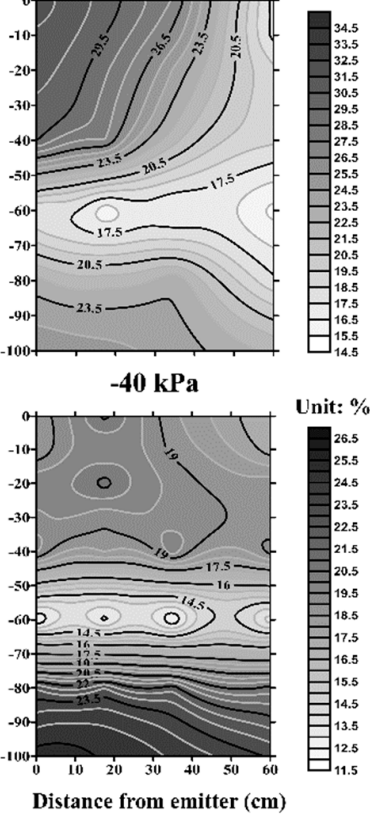

$-40 \mathrm{kPa}$

Figure 7. Spatial distribution of soil moisture along the vertical transect that is perpendicular to the drip line (A) before spring irrigation, (B) before sowing, (C) before the irrigation at the jointing stage, (D) after the irrigation at the jointing stage, and (E) after harvest, for all treatments in 2016. 


\subsection{Distribution of Soil Salt}

Along with soil water, soil salt moved vertically and horizontally, mainly influenced by rainfall, irrigation, evaporation, root water uptake and recharge of groundwater. As shown in Figure 8A-E and Figure 9A-E, the spatial distributions and variation trend of soil salt along the vertical profiles perpendicular to the drip line was similar in 2015 and 2016.

Before spring irrigation, an obvious soil salt gradient above $60 \mathrm{~cm}$ existed, specifically, the soil salt gradually decreased from $3.2 \mathrm{~g} / \mathrm{kg}$ on the surface to $1.6 \mathrm{~g} / \mathrm{kg}$ as soil depth increased to $50-60 \mathrm{~cm}$, and slightly increased to $1.8 \mathrm{~g} / \mathrm{kg}$ at $60-100 \mathrm{~cm}$. Meanwhile, the salt distribution in 60-100 $\mathrm{cm}$ had little difference in response to treatments, which may be caused by soil spatial heterogeneity (Figures $9 \mathrm{~A}$ and $10 \mathrm{~A})$.

Before sowing, soil salt above $80 \mathrm{~cm}$ decreased distinctly when compared with soil salt before spring irrigation. Visibly, the soil salt content was below $1.4 \mathrm{~g} / \mathrm{kg}$ owing to the leaching of spring irrigation, which was lower than the tolerance threshold of corn of $5.39 \mathrm{~g} / \mathrm{kg}$ [21]. Meanwhile, an obvious soil salt gradient within $70-100 \mathrm{~cm}$ existed, with soil salt increasing from $1.6 \mathrm{~g} / \mathrm{kg}$ to $3.0 \mathrm{~g} / \mathrm{kg}$ in response to the leaching of spring irrigation, and a massive amount of salt moving downward to deeper layers along with the irrigation water.

Before the irrigation at the jointing stage, the distribution of soil salt for treatments was similar, and soil salinity of zone the at $0-40 \mathrm{~cm}$ distance from the drip emitter at $0-40 \mathrm{~cm}$ depth for treatments was in the order of $-10 \mathrm{kPa}<-20 \mathrm{kPa}<-30 \mathrm{kPa}<-40 \mathrm{kPa}$, while soil salt content of layers at $40-100 \mathrm{~cm}$ depth was in the order of $-10 \mathrm{kPa}>-20 \mathrm{kPa}>-30 \mathrm{kPa}>-40 \mathrm{kPa}$. Meanwhile, there was a low-salt area at about $20 \mathrm{~cm}$ distance from the drip emitter at $0-40 \mathrm{~cm}$ depth, where maize main roots were distributed, whereas, the zone of $40-60 \mathrm{~cm}$ distance from the drip emitter at 0-40 cm depth exhibited high salinity.

After the irrigation at the jointing stage, soil salinity at $0-40 \mathrm{~cm}$ distance from the drip emitter decreased to $1.1 \mathrm{~g} / \mathrm{kg}$, while soil salt content at $40-60 \mathrm{~cm}$ distance from the drip emitter at $0-40 \mathrm{~cm}$ depth increased. Meanwhile, soil salinity at $40-100 \mathrm{~cm}$ increased after the irrigation with saline water, while, with drip emitter as the focus, the soil salinity area at 0-60 $\mathrm{cm}$ depth was a one-quarter ellipse in the vertical profile perpendicular to the drip line, and the vertical radius was longer than the horizontal radius.

After harvest, the distribution of soil salt at $40-100 \mathrm{~cm}$ was similar for all treatments, and there was an obvious soil salt gradient with soil depths of 0-100 cm. Moreover, the soil salt content decreased with the soil depth, while soil salinity at the same distance from the drip emitter and the same depth for treatments was in the order of $-10 \mathrm{kPa}>-20 \mathrm{kPa}>-30 \mathrm{kPa}>-40 \mathrm{kPa}$.

Overall, with the point source infiltration, the shape of the wetting body was similar to a one-quarter ellipse in the vertical profile perpendicular to the drip line. With maize roots slightly taking some ions, a low soil salinity area in the root zone occurred. Moreover, the evaporation of topsoil resulted in the motivation of deep soil salt toward the surface, and soil salt moved toward the un-mulched area (40-60 $\mathrm{cm}$ distance from the drip emitter). 

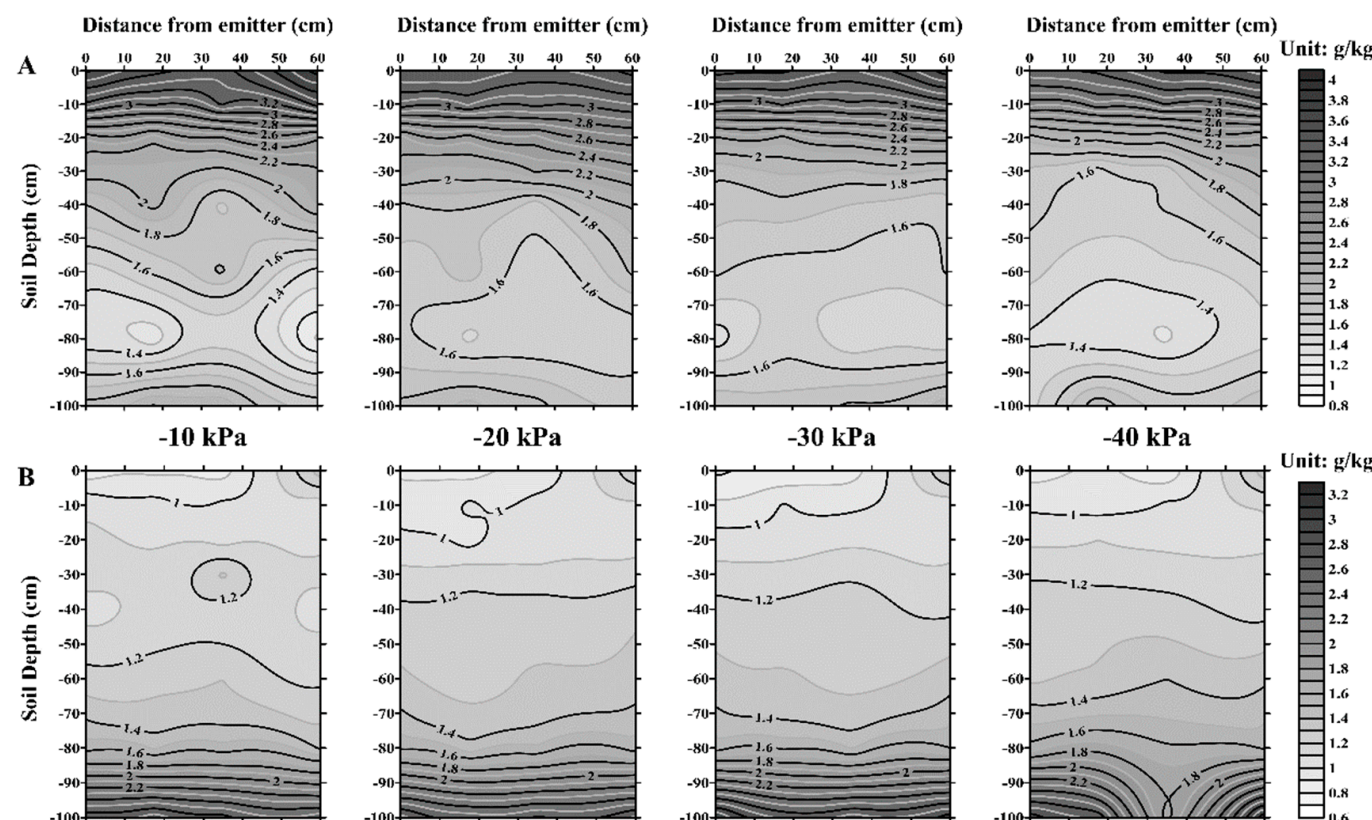

$-20 \mathrm{kPa}$
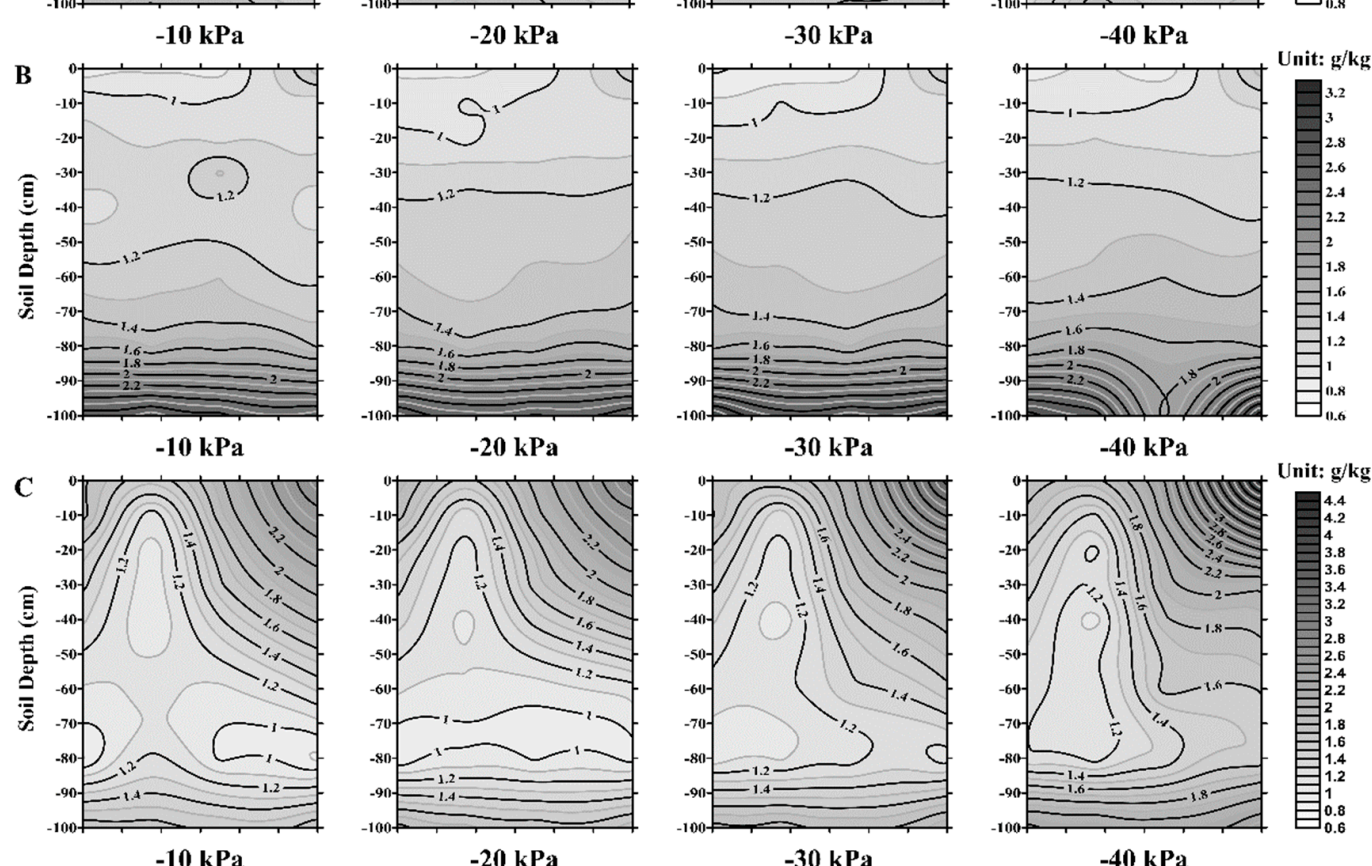

$-20 \mathrm{kPa}$

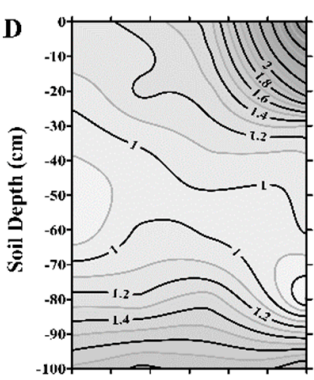

$-10 \mathrm{kPa}$

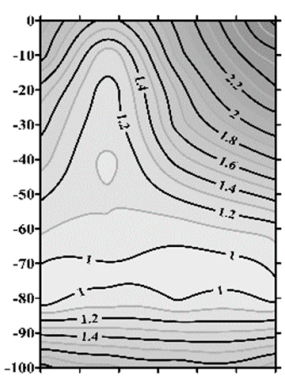

$-30 \mathrm{kPa}$

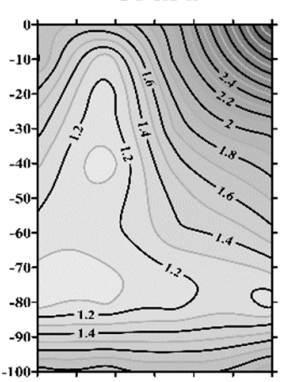

$-40 \mathrm{kPa}$

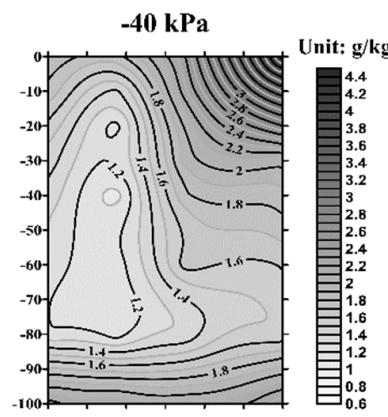

$-20 \mathrm{kPa}$

$-30 k P a$

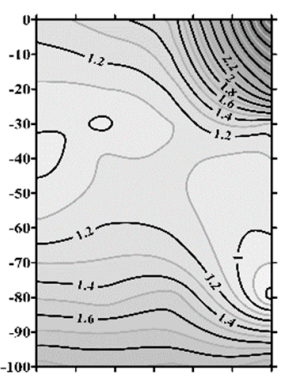

$-20 \mathrm{kPa}$
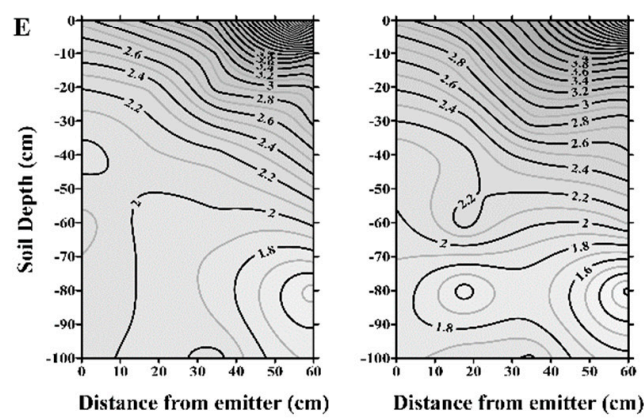

$-20 \mathrm{kPa}$

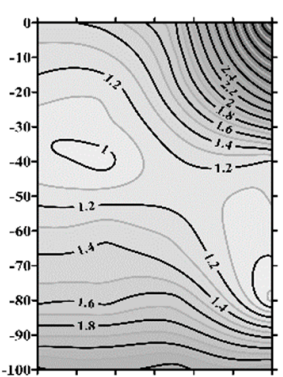

$-40 \mathrm{kPa}$

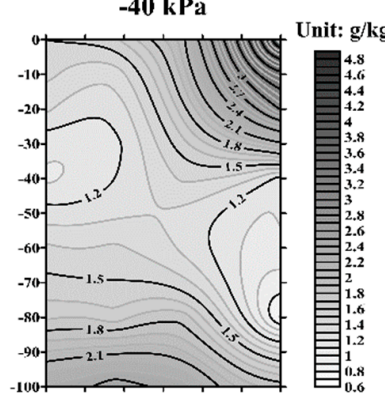

$-30 \mathrm{kPa}$

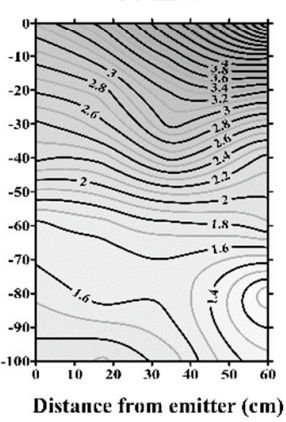

$-40 \mathrm{kPa}$

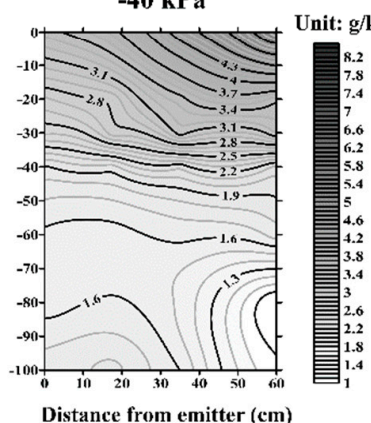

$-30 \mathrm{kPa}$

$-40 \mathrm{kPa}$

Figure 8. Spatial distribution of soil salt $\left(\mathrm{g} \cdot \mathrm{kg}^{-1}\right)$ along the vertical transect that is perpendicular to the drip line (A) before spring irrigation, (B) before sowing, (C) before the irrigation at the jointing stage, (D) after the irrigation at the jointing stage, and (E) after harvest, for all treatments in 2015. 


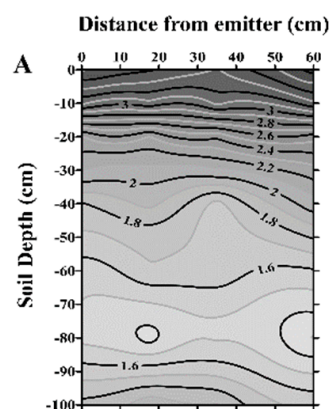

$10 \mathrm{kPa}$

B

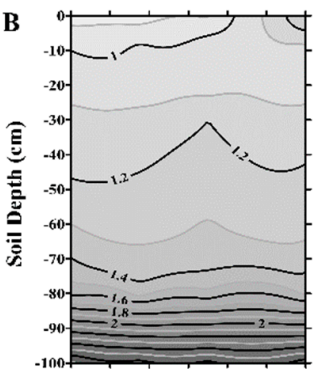

$-10 \mathrm{kPa}$

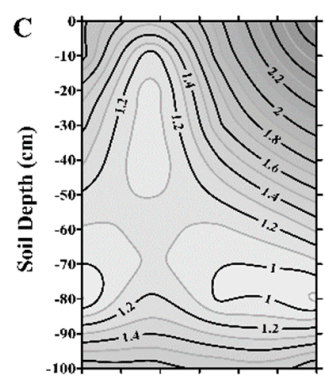

$-10 \mathrm{kPa}$

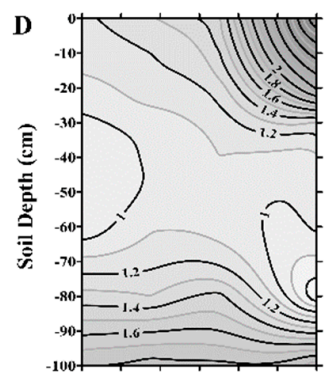

$-10 \mathrm{kPa}$

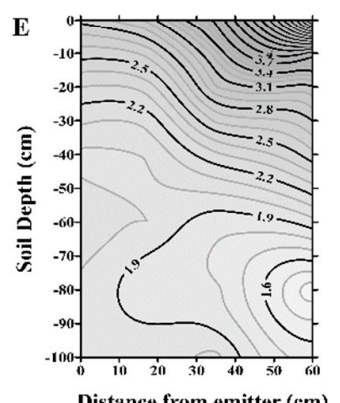

$-10 \mathrm{kPa}$

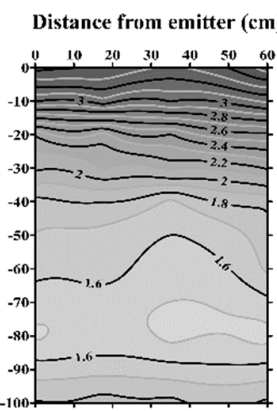

$-20 \mathrm{kPa}$

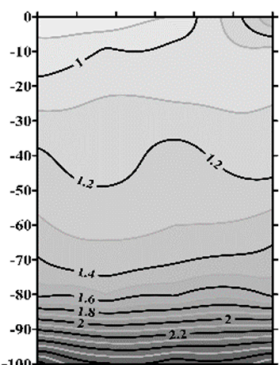

$-20 \mathrm{kPa}$

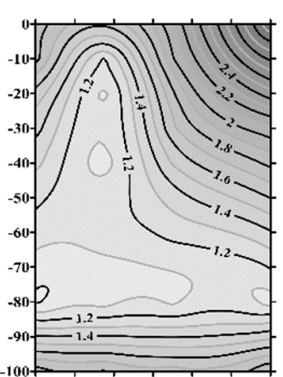

$-20 \mathrm{kPa}$

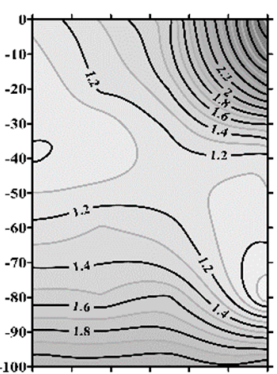

$-20 \mathrm{kPa}$

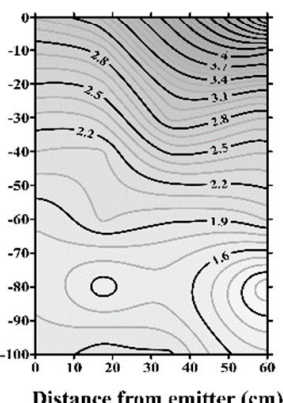

$-20 \mathrm{kPa}$

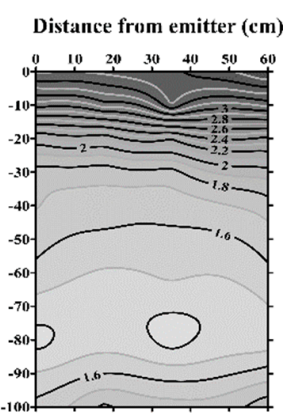

$-30 \mathrm{kPa}$

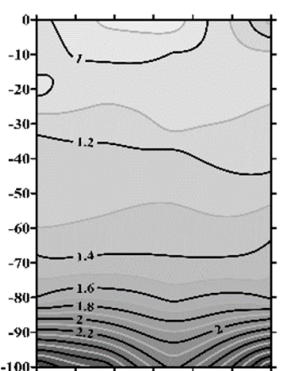

$-30 \mathrm{kPa}$

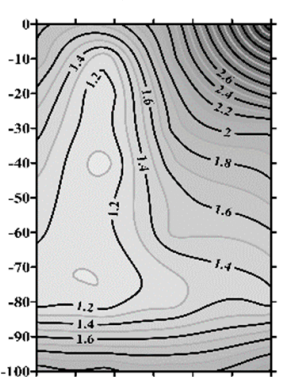

$-30 \mathrm{kPa}$

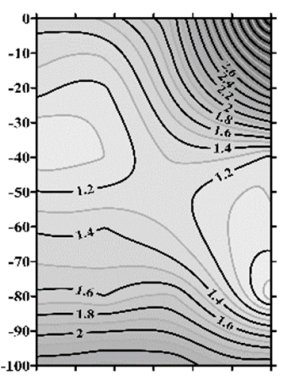

$-30 \mathrm{kPa}$

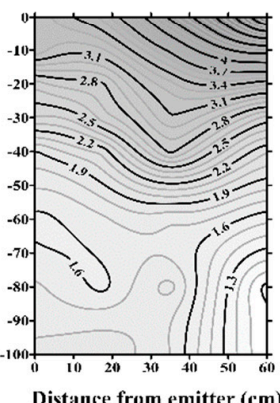

$-30 \mathrm{kPa}$

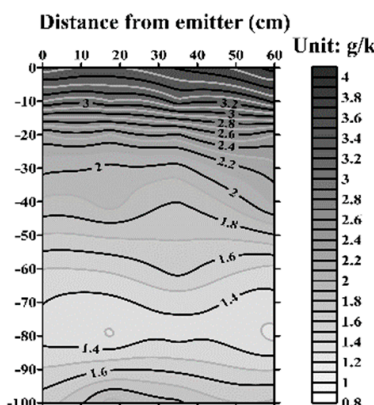

$-40 \mathrm{kPa}$

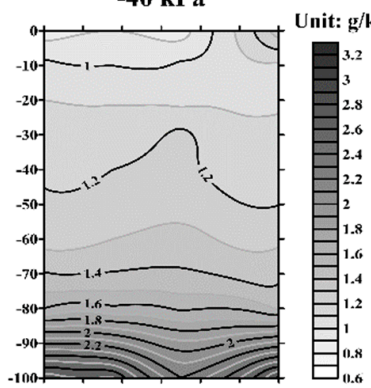

$-40 \mathrm{kPa}$

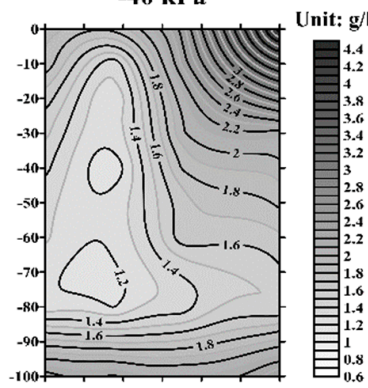

$-40 \mathrm{kPa}$

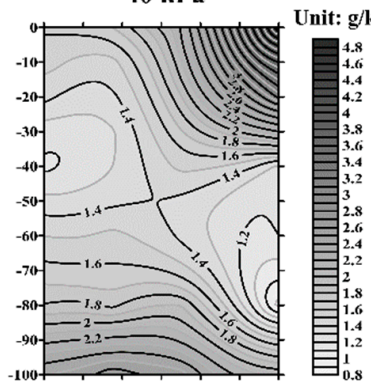

$-40 \mathrm{kPa}$

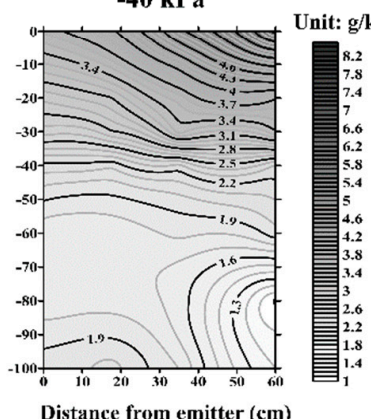

$-40 \mathrm{kPa}$

Figure 9. Spatial distribution of soil salt $\left(\mathrm{g} \cdot \mathrm{kg}^{-1}\right)$ along the vertical transect that is perpendicular to the drip line (A) before spring irrigation, (B) before sowing, (C) before the irrigation at the jointing stage, (D) after the irrigation at the jointing stage, and (E) after harvest, for all treatments in 2016. 


\subsection{Soil Salt Accumulation}

The soil salt accumulations after saline water irrigation at different thresholds in 2015 and 2016 are shown in Figure 10A,B, respectively. Results show that salt accumulated in the 0-100 cm layer. Moreover, influenced by precipitation, irrigation and evaporation, salt accumulation decreased with the increasing thresholds and the increasing depth in the $0-40 \mathrm{~cm}$ layer. whereas, salt accumulation in the 40-100 cm layer was not notable with the influence of saline water irrigation and groundwater recharge.

The saline water irrigation not only supplied moisture for maize growth, but also provided extra water for leaching soil salt via vertical and lateral infiltration. Moreover, the influence of desalinization evoked by irrigation and rainfall decreased with the increasing soil depth, while, due to ground water depth from May to June being lower than $3.0 \mathrm{~m}$, salt of the recharged saline water from underground gathered in layers below $60 \mathrm{~cm}$.
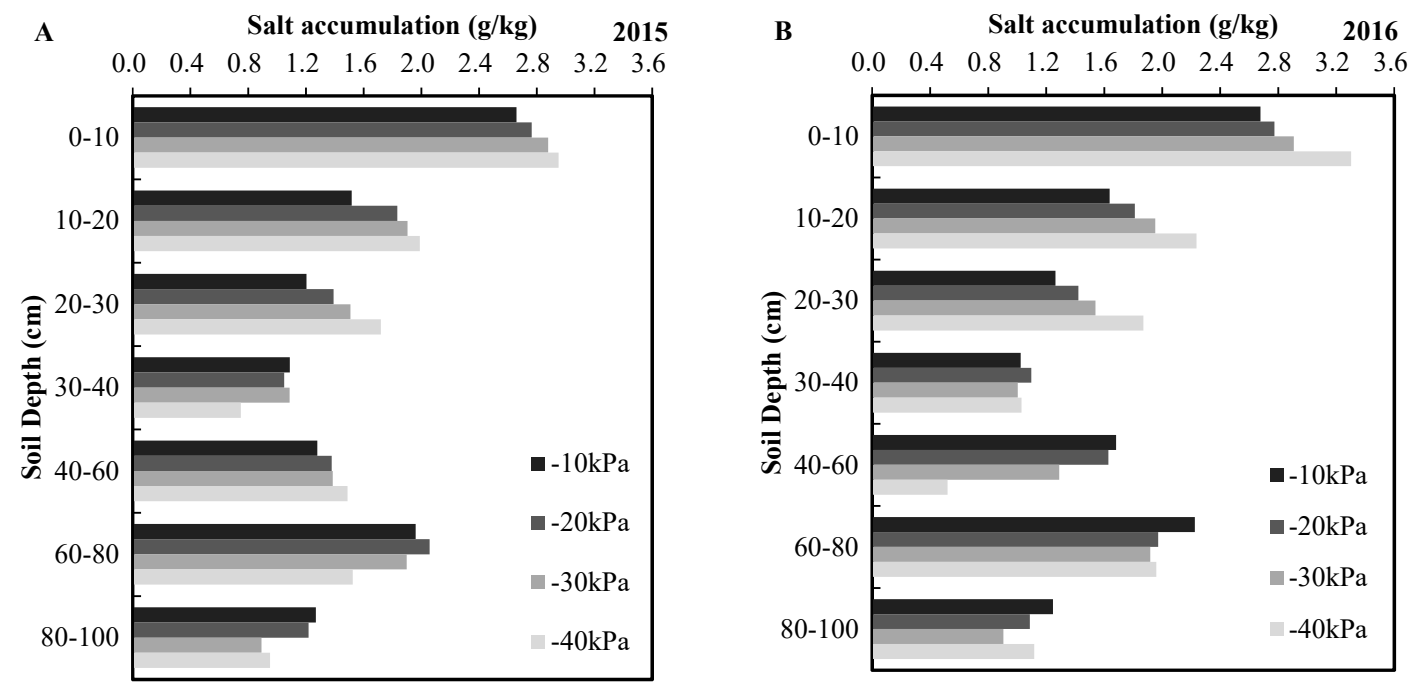

Figure 10. Soil salt $\left(\mathrm{g} \cdot \mathrm{kg}^{-1}\right)$ accumulation for saline water irrigation: (A) soil salt $\left(\mathrm{g} \cdot \mathrm{kg}^{-1}\right)$ accumulation in 2015; (B) soil salt $\left(\mathrm{g} \cdot \mathrm{kg}^{-1}\right)$ accumulation in 2016.

\subsection{Yield of Maize}

\subsubsection{Yield Characteristics}

As shown in Table 7, there were little differences in ear length, 100-kernel weight and fresh ear weight of maize for treatments: the parameters all decreased with the decreasing target SMP. Meanwhile, high target thresholds with more saline water exerted positive effects on ear length, 100-kernel weight and fresh ear weight; in this case, all yield parameters of the $-40 \mathrm{kPa}$ treatment were the lowest.

Table 7. The yield characteristics for treatments in 2015 and 2016.

\begin{tabular}{|c|c|c|c|c|c|c|c|c|}
\hline Years & Treatments & $\begin{array}{l}\text { Ear Length } \\
(\mathrm{cm})\end{array}$ & $\begin{array}{c}\text { Ear Diameter } \\
(\mathrm{cm})\end{array}$ & $\begin{array}{c}\text { Kernel } \\
\text { Rows } \\
\text { per Ear }\end{array}$ & $\begin{array}{l}\text { Kernel } \\
\text { per Row }\end{array}$ & $\begin{array}{l}\text { Kernel } \\
\text { per Ear }\end{array}$ & $\begin{array}{l}\text { 100-Kernel } \\
\text { Weight (g) }\end{array}$ & $\begin{array}{c}\text { Fresh Ear } \\
\text { Weight (g) }\end{array}$ \\
\hline \multirow{4}{*}{2015} & $\mathrm{~S} 1(-10 \mathrm{kPa})$ & $18.146 \mathrm{c}$ & $45.104 \mathrm{~b}$ & $16.804 \mathrm{~b}$ & $28.628 \mathrm{a}$ & $504.800 \mathrm{~b}$ & $31.970 \mathrm{c}$ & $164.690 \mathrm{~d}$ \\
\hline & $\mathrm{S} 2(-20 \mathrm{kPa})$ & $18.140 \mathrm{c}$ & $45.140 \mathrm{~b}$ & $17.200 \mathrm{c}$ & $31.164 \mathrm{~d}$ & $517.400 \mathrm{c}$ & $31.370 \mathrm{~b}$ & $157.600 \mathrm{~b}$ \\
\hline & $\mathrm{S} 3(-30 \mathrm{kPa})$ & $17.636 \mathrm{~b}$ & $45.872 \mathrm{~b}$ & $17.600 \mathrm{~d}$ & $30.044 \mathrm{c}$ & $515.400 \mathrm{c}$ & $31.318 \mathrm{~b}$ & $161.236 \mathrm{c}$ \\
\hline & $\mathrm{S} 4(-40 \mathrm{kPa})$ & $17.502 \mathrm{a}$ & $43.156 \mathrm{a}$ & $16.614 \mathrm{a}$ & $29.296 \mathrm{~b}$ & $492.200 \mathrm{a}$ & $29.576 \mathrm{a}$ & $138.680 \mathrm{a}$ \\
\hline \multirow{4}{*}{2016} & $\mathrm{~S} 1(-10 \mathrm{kPa})$ & $17.186 \mathrm{~d}$ & $47.004 \mathrm{~b}$ & $16.604 \mathrm{~b}$ & $28.004 \mathrm{a}$ & $496.000 \mathrm{~b}$ & 31.192 c & $175.556 \mathrm{~d}$ \\
\hline & $\mathrm{S} 2(-20 \mathrm{kPa})$ & $16.980 \mathrm{c}$ & $47.680 \mathrm{~b}$ & $17.412 \mathrm{c}$ & $31.578 \mathrm{~d}$ & $513.000 \mathrm{c}$ & $31.052 \mathrm{c}$ & $145.556 \mathrm{~b}$ \\
\hline & $\mathrm{S} 3(-30 \mathrm{kPa})$ & $16.080 \mathrm{~b}$ & $46.422 \mathrm{ab}$ & $17.600 \mathrm{~d}$ & $29.870 \mathrm{c}$ & $517.200 \mathrm{~d}$ & $30.290 \mathrm{~b}$ & $167.680 \mathrm{c}$ \\
\hline & $\mathrm{S} 4(-40 \mathrm{kPa})$ & $14.766 \mathrm{a}$ & $45.068 \mathrm{a}$ & $16.212 \mathrm{a}$ & $29.368 \mathrm{~b}$ & $487.200 \mathrm{a}$ & $27.590 \mathrm{a}$ & $140.000 \mathrm{a}$ \\
\hline
\end{tabular}

Note: Values in a row followed by the same letter are not significantly different at $p \leq 0.05$, while values in a row followed by different letters are significantly different at $p \leq 0.05$. 


\subsubsection{Yield and IWUE}

IWUE was calculated by Equation (2). Maize yield and IWUE increased with the increase of SMP, while the corresponding IWUE decreased with the increase of SMP (Table 8). As shown in Table 8, the yield of the S1 treatment was higher than other treatments, while the IWUE was the lowest. In contrast, the IWUE of the S4 treatment was the highest, but the yield was lower than for other treatments. The yield of the S3 treatment was just $0.36 \%$ and $0.84 \%$ lower than that of the S2 treatment in 2015 and 2016, respectively, while the IWUE of the S3 treatment was $18.46 \%$ and $21.57 \%$ higher than that of the S2 treatment in 2015 and 2016, respectively. The detailed relationship between maize yield, IWUE and SMP is illustrated in Figure 11. In both 2015 and 2016, the IWUE increased lineally with the decrease of SMP, while maize yield increased slowly with the decrease of SMP at first, and reached the maximum value when SMP reached about $-20 \mathrm{kPa}$, and then decreased rapidly as the SMP decreased, which is in accordance with the research of Wang et al. [16].

The present study was aimed at determining a reasonable irrigation regime for maize production, based on comprehensive consideration of high yield, little salt accumulation and high IWUE. Hence, the irrigation schedule using local shallow saline groundwater with SMP of $-30 \mathrm{kPa}$ is recommended in the study area.

Table 8. Maize yield and irrigation water use efficiency (IWUE) for treatments in 2015 and 2016.

\begin{tabular}{cccccc}
\hline Years & Treatments & SMP (-kPa) & Yield (kg/ha) & $\begin{array}{c}\text { Irrigation Amount of } \\
\text { Saline Water (mm) }\end{array}$ & $\begin{array}{c}\text { IWUE } \\
\mathbf{( k g / h a / m m})\end{array}$ \\
\hline \multirow{2}{*}{2015} & S1 $(-10 \mathrm{kPa})$ & 10 & $14,182.000 \mathrm{c}$ & 472.5 & $30.013 \mathrm{a}$ \\
& $\mathrm{S} 2(-20 \mathrm{kPa})$ & 20 & $14,090.000 \mathrm{~b}$ & 360.0 & $39.140 \mathrm{~b}$ \\
& $\mathrm{~S} 3(-30 \mathrm{kPa})$ & 30 & $14,039.000 \mathrm{~b}$ & 292.5 & $48.000 \mathrm{c}$ \\
& $\mathrm{S} 4(-40 \mathrm{kPa})$ & 40 & $13,032.667 \mathrm{a}$ & 225.0 & $57.923 \mathrm{~d}$ \\
\hline \multirow{2}{*}{2016} & $\mathrm{~S} 1(-10 \mathrm{kPa})$ & 10 & $14,182.000 \mathrm{c}$ & 540.0 & $26.263 \mathrm{a}$ \\
& $\mathrm{S} 2(-20 \mathrm{kPa})$ & 20 & $14,076.000 \mathrm{bc}$ & 405.0 & $34.753 \mathrm{~b}$ \\
& $\mathrm{~S} 3(-30 \mathrm{kPa})$ & 30 & $13,958.000 \mathrm{~b}$ & 315.0 & $44.313 \mathrm{c}$ \\
& $\mathrm{S} 4(-40 \mathrm{kPa})$ & 40 & $13,040.667 \mathrm{a}$ & 247.5 & $52.690 \mathrm{~d}$ \\
\hline
\end{tabular}

Note: Values in a row followed by the same letter are not significantly different at $p \leq 0.05$, while values in a row followed by different letters are significantly different at $p \leq 0.05$.

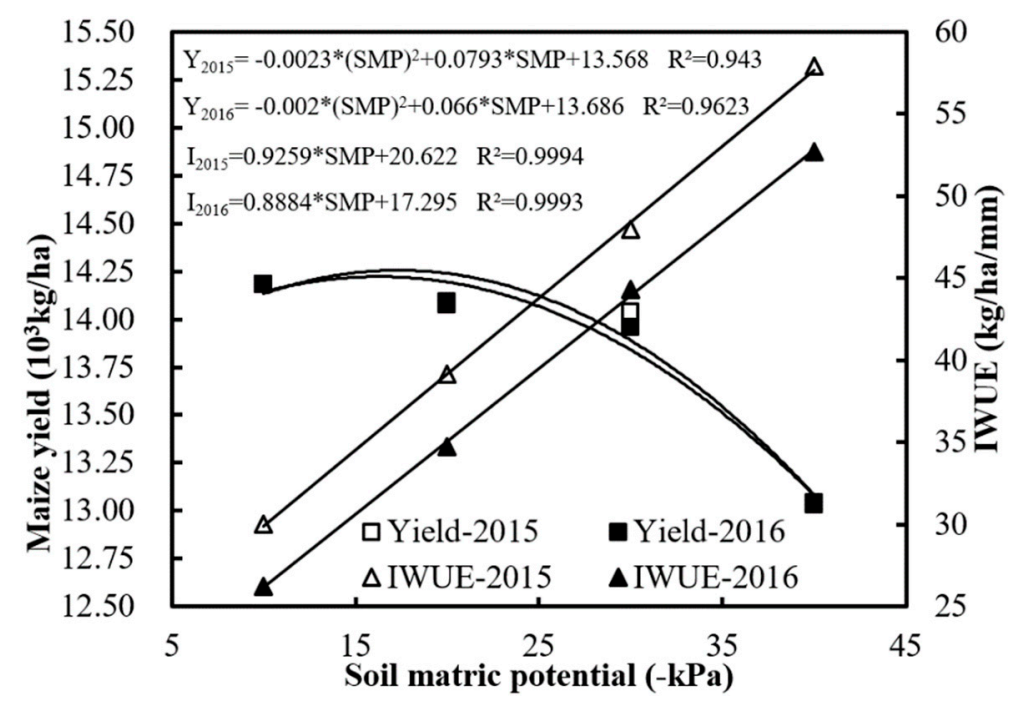

Figure 11. The relationship between maize yield, IWUE, and SMP in 2015 and 2016.

\section{Discussion}

According to the two-year field experiment conducted in HID, soil moisture and soil salt revealed a short-term fluctuation during the maize growth period. A low-salt zone in the plough layer and a 
high-salt region in the topsoil out of the mulch emerged, and the isoline distribution of soil salt was similar to that of soil moisture. Moreover, as a result of point source infiltration, a wetting body similar to a one-quarter ellipse in the vertical profile perpendicular to the drip line emerged. The horizontal radius of the wetting body increased with the increase of SMP, while the vertical radius remained at $40 \mathrm{~cm}$ despite variation in SMP from $-40 \mathrm{kPa}$ to $-10 \mathrm{kPa}$, which illustrates that the wetted depth in loam was $40 \mathrm{~cm}$ under a drip irrigation quota of $22.5 \mathrm{~mm}$. The result of the present study is consistent with the research of Zheng et al. (2011), who indicated that an inverted cone of the soil-wetted zone and a salt shell outside the wetting body formed after drip irrigation [22].

With the influence of saline water irrigation, rainfall, strong evaporation and groundwater recharge, salt accumulation decreased with the increasing thresholds in the $0-40 \mathrm{~cm}$ layer, which is similar to the research of Feng et al. [23] and Liu et al. [24]. However, the SMP had no significant effect on soil salinity in the 40-100 cm layer, which is different from the research of Qiao et al. [25], who found that salt accumulation does not appear in the $0-100 \mathrm{~cm}$ soil layer during the whole growth stage of summer maize, when the water salinity level is lower than $4.0 \mathrm{~g} / \mathrm{L}$ and groundwater depth is higher than $3 \mathrm{~m}$.

With shallow saline groundwater drip irrigation, the ear length, 100-kernel weight and fresh ear weight of maize decreased with the decrease of target SMP. Moreover, the IWUE increased lineally in response to the decrease of the SMP threshold, while maize yield showed a quadratic relationship with the SMP threshold, with maximum production reached at a SMP of $-20 \mathrm{kPa}$. These findings are concordant with those of Wan et al. [17]. Considering the considerable yield, litter salt accumulation and high IWUE, the irrigation system of $S 3(-30 \mathrm{kPa})$ is recommended for maize production in the study area.

It should be noted that the conclusions of this study were based on two years of field experiment data, and the detailed dynamic response of groundwater salinity, groundwater level and soil salinity was not investigated. Further study of the possible impacts of saline water irrigation on soil, crops and the groundwater environment remains for the future.

Author Contributions: Conceptualization, J.L. and Z.Q.; Data curation, Z.Q.; Formal analysis, J.L.; Funding acquisition, Z.Q.; Investigation, J.L.; Methodology, Z.Q.; Project administration, J.C.; Resources, F.W.; Software, J.L.; Validation, J.L., Z.Q. and J.C.; Visualization, Q.J.; Writing-Original Draft, J.L.; Writing—Review \& Editing, Z.Q.

Funding: This research was funded by "The National Key Research and Development Program of China”, grant number "2016YFC0501301".

Acknowledgments: We are grateful to Pingru He for her constructive comments during the review process. We also thank Yongping Huang for his help in the field.

Conflicts of Interest: The authors declare no conflict of interest.

\section{References}

1. Yu, M.; Rui, X.F. Review of improvement and utilization of saline-alkali field in Ningxia Hui Autonomous Region. Adv. Sci. Technol. Water Resour. 2006, 26, 85-89, (In Chinese with English Abstract).

2. Yao, Y.L. A study on the development and utilization direction of the low-lying saline-alkali wasteland in the Yellow River irrigation region in Ningxia. J. Nat. Resour. 1995, 10, 364-371, (In Chinese with English Abstract).

3. Chauhan, C.P.S.; Singh, R.B.; Gupta, S.K. Supplemental irrigation of wheat with saline water. Agric. Water Manag. 2008, 95, 253-258. [CrossRef]

4. Jiang, J.; Huo, Z.L.; Feng, S.Y.; Zhang, C.B. Effect of irrigation amount and water salinity on water consumption and water productivity of spring wheat in Northwest China. Field Crop Res. 2012, 137, 78-88. [CrossRef]

5. Ma, W.J.; Chen, Q.J.; Li, L.T.; Yu, Z.R.; Niu, L.A. Effect of soil water dynamic changes and crop yield with saline water irrigation. Trans. CSAE 2010, 26, 73-80, (In Chinese with English Abstract). [CrossRef] 
6. Jack, K.; Ron, D.B. Sprinkle and Trickle Ago-irrigation Overview. In Sprinkle and Trickle Irrigation; Van Nostrand Reinhold: New York, NY, USA, 1990; p. 22. ISBN 978-1-4757-1427-2.

7. Min, W.; Guo, H.J.; Zhou, G.W.; Zhang, W.; Ma, L.J.; Ye, J.; Hou, Z.A. Root distribution and growth of cotton as affected by drip irrigation with saline water. Field Crops Res. 2014, 169, 1-10. [CrossRef]

8. Hou, Z.N.; Chen, W.P.; Li, X.; Xiu, L.; Wu, L.S. Effects of salinity and fertigation practice on cotton yield and $15 \mathrm{~N}$ recovery. Agric. Water Manag. 2009, 96, 1483-1489. [CrossRef]

9. Anikwe, M.A.N.; Mbah, C.N.; Ezeaku, P.I.; Onyia, V.N. Tillage and plastic mulch effects on soil properties and growth and yield of cocoyam (Colocasia esculenta) on an ultisol in southeastern Nigeria. Soil Tillage Res. 2007, 93, 264-272. [CrossRef]

10. Dong, H.Z.; Li, W.J.; Tang, W.; Zhang, D.M. Early plastic mulching increases stand establishment and lint yield of cotton in saline fields. Field Crops Res. 2009, 111, 269-275. [CrossRef]

11. Li, X.B.; Kang, Y.H.; Wan, S.Q.; Chen, X.L.; Chu, L.L. Reclamation of very heavy coastal saline soil using drip-irrigation with saline water on salt sensitive plants. Soil Tillage Res. 2015, 146, 159-173. [CrossRef]

12. Wang, Q.M.; Huo, Z.L.; Zhang, L.D.; Wang, J.H.; Zhao, Y. Impact of saline water irrigation on water use efficiency and soil salt accumulation for spring maize in arid regions of China. Agric. Water Manag. 2016, 163, 125-138. [CrossRef]

13. Kang, Y.H.; Wan, S.Q. Effect of soil water potential on radish (Raphanus sativus L.) growth and water use under drip irrigation. Sci. Hortic. 2005, 106, 275-292. [CrossRef]

14. Jiao, Y.P.; Kang, Y.H.; Wan, S.Q.; Liu, W.; Dong, F. Effect of soil matric potential on waxy corn growth and irrigation water use efficiency under mulch drip irrigation in saline soils of arid areas. Agric. Res. Arid Areas 2007, 25, 144-151, (In Chinese with English Abstract).

15. Tan, J.L.; Kang, Y.H.; Jiao, Y.P.; Sun, Z.Q.; Liu, W.; Dong, F.; Li, K.W. Characteristics of soil salinity and salt ions distribution in salt-affected field under mulch-drip irrigation in different planting years. Trans. CASE 2008, 24, 59-63, (In Chinese with English Abstract).

16. Wang, R.S.; Kang, Y.H.; Wan, S.Q.; Hu, W.; Liu, S.P.; Liu, S.H. Salt distribution and the growth of cotton under different drip irrigation regimes in a saline area. Agric. Water Manag. 2011, 100, 58-69. [CrossRef]

17. Wan, S.Q.; Jiao, Y.P.; Kang, Y.H.; Hu, W.; Jiang, S.F.; Tan, J.L.; Liu, W. Drip irrigation for waxy corn (Zea mays L. var. certain Kulesh) for production in highly saline conditions. Agric. Water Manag. 2011, 104, 210-220. [CrossRef]

18. Sun, J.X.; Kang, Y.H.; Wan, S.Q.; Hu, W.; Jiang, S.F.; Zhang, T.B. Soil salinity management with drip irrigation and its effects on soil hydraulic properties in north China coastal saline soils. Agric. Water Manag. 2012, 115, 10-19. [CrossRef]

19. Li, X.B. Salt leaching and Iris germanica L. growth in two coastal saline soils under drip irrigation with saline water. Sci. Hortic. 2018, 237, 164-168. [CrossRef]

20. Wang, R.S.; Wan, S.Q.; Sun, J.X.; Xiao, H.J. Soil salinity, sodicity and cotton yield parameters under different drip irrigation regimes during saline wasteland reclamation. Agric. Water Manag. 2018, 209, 20-31. [CrossRef]

21. Jiao, Y.P.; Gao, W.; Pan, Z.H.; Li, K.J.; Shen, G.C. Effect of saline water irrigation on soil salt dynamics and yields of wheat and maize in low plain of Hebei province. Agric. Res. Arid Areas 2013, 31, 134-140. (In Chinese with English Abstract).

22. Zheng, X.H.; Batur, B.; Li, H.; Jia, W.H.; Zhao, H.Z. Effect of irrigation methods on movement of soil water and salt in arid area. J. Northeast Agric. Univ. 2011, 42, 95-101. (In Chinese with English Abstract). [CrossRef]

23. Feng, D.; Wan, S.; Kang, Y.; Xue, Z.; Zhang, T. Drip irrigation scheduling for annual crops in an impermeable saline-sodic soil with an improved method. J. Soil Water Conserv. 2017, 72, 351-360. [CrossRef]

24. Liu, S.H.; Kang, Y.H.; Wan, S.Q.; Wang, Z.C.; Liang, Z.W.; Sun, X.J. Water and salt regulation and its effects on Leymus chinensis growth under drip irrigation in saline-sodic soils of the Songnen Plain. Agric. Water Manag. 2011, 98, 1469-1476. [CrossRef]

25. Qiao, D.M.; Wu, H.Q.; Qi, X.B.; Hu, C.; Zhu, D.H.; Fan, X.Y. Simulation and Movement Regularity of Soil Water and Soil Salt by Brackish Water Irrigation under Condition of Different Groundwater Depth. J. Soil Water Conserv. 2007, 21, 7-10, 15, (In Chinese with English Abstract). [CrossRef]

(C) 2018 by the authors. Licensee MDPI, Basel, Switzerland. This article is an open access article distributed under the terms and conditions of the Creative Commons Attribution (CC BY) license (http:/ / creativecommons.org/licenses/by/4.0/). 